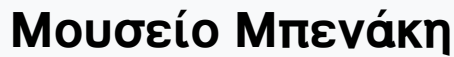

Tóp. 3 (2003)

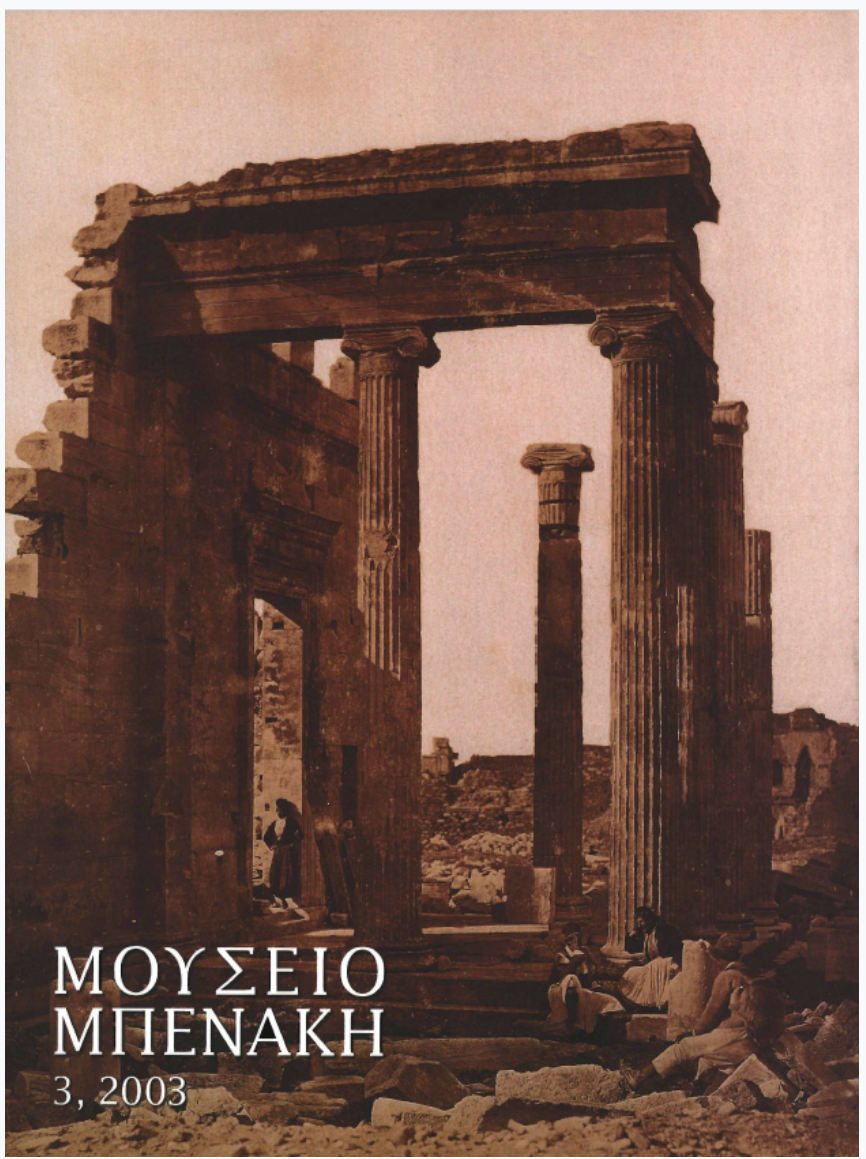

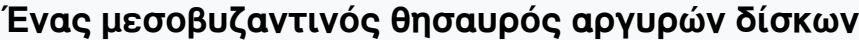

Anna Ballian, Anastasia Drandaki

doi: $10.12681 /$ benaki.18209

Copyright @ 2018, Anna Ballian, Anastasia Drandaki

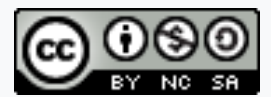

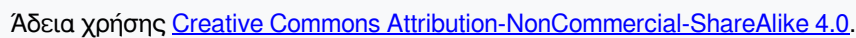

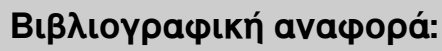

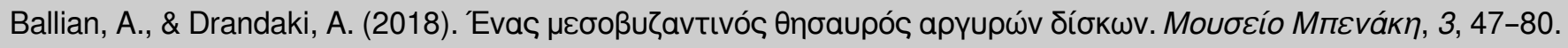
https://doi.org/10.12681/benaki.18209 


\section{A Middle Byzantine silver treasure}

Since October 2003 there has been on display at the Benaki Museum a unique treasure consisting of nine silver-gilt dishes dating from the Middle Byzantine era, which has been offered for sale to Greece. The three largest Byzantine collections in the country, the Byzantine and Christian Museum in Athens, the Museum of Byzantine Culture in Thessaloniki and the Benaki Museum, have jointly undertaken the task of raising the necessary funds to acquire this treasure so that it can remain in Greece, and with this aim the dishes were also exhibited for two weeks in Thessaloniki. At the time of writing this initiative by the three museums is still proceeding apace.

The nine dishes were previously unknown both to specialists and to the general public. The astonishment which greeted the appearance of such a treasure can be imagined, not only because it comprises rare and precious objects in an excellent state of preservation, but also because the material is largely unfamiliar and opens up a wide variety of new paths and horizons for the study of Middle Byzantine art. The present article takes the form of a general introduction to the subject; it would certainly not claim to cover all the issues involved, nor to do more than present the basic information and indicate the specific features which locate the dishes in their chronological and cultural context.

The nine dishes were inherited by the present owner from his father, who acquired them in 1937 for $£ 15,000$ from A. Barry, an Englishman, who had been an exporter of currants in Smyrna until 1922, when he settled in Patras.' The provenance of the dishes is not known with certainty, but according to undocumented information from the original owner they were discovered accidentally outside Tatar Pazarcik in modern Bulgaria. The dishes were cleaned before being offered for sale and their condition is generally excellent, though in many places the gilding is missing. Some display marks which postdate their manufacture and are evidence of a change of owner or of tests made from time to time to establish the purity of the alloy and the commercial value of the objects.

Two dishes (nos 1 and 2) are footed (figs 1-2), while the others have a flat base and low, rising sides (figs 3-6). Three display human figures on the central medallion, in representations of a hunting scene (figs 1 and 3) and of the Sea riding on a sea monster (fig. 4). The others have vegetal and geometrical ornamentation. A detailed description of the dishes, with their dimensions, can be found in the Appendix to this article.

\section{Technical data - the shapes}

The composition of the alloy on five of the plates was analysed by the Demokritos Nuclear Physics Institute when the treasure was first examined. The results are presented in the following article by the metal conservator of the Benaki Museum, Despina Kotzamani. But at this point certain observations should be made. The plates which were analysed were manufactured from an alloy with a high silver content varying from 93.6 to $95 \%$, while the composition also contained amounts of copper (3.11-4.72\%), gold (1.26-1.49\%) and lead (0.37$1.15 \%)$ which are normal for mediaeval silver vessels. ${ }^{2}$ The five vessels have a similar alloy composition with few 

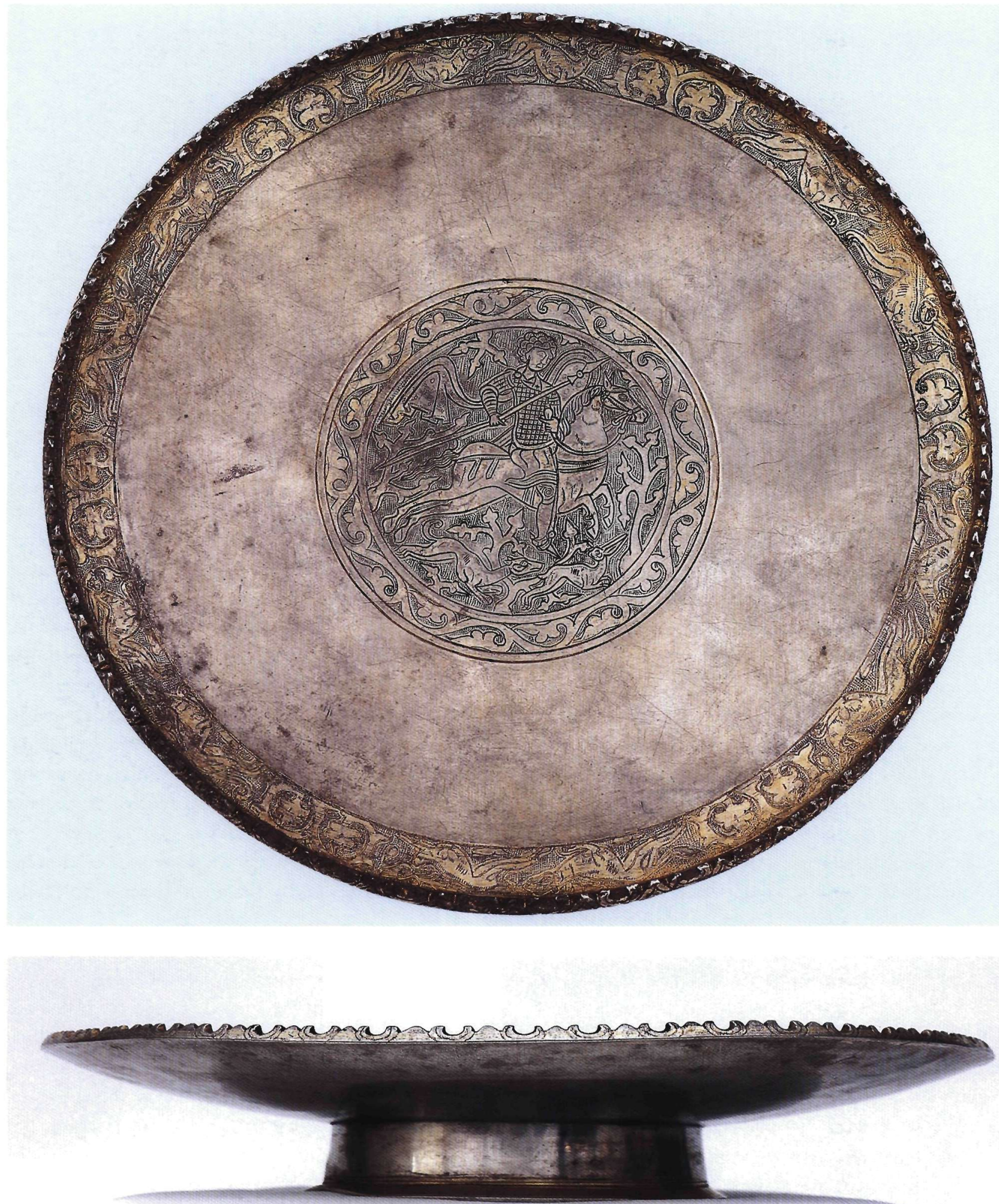

Fig. 1 a-b. Footed plate no. 1 with a mounted huntsman and running animals. Private collection (photos: Sp. Delivorrias). 


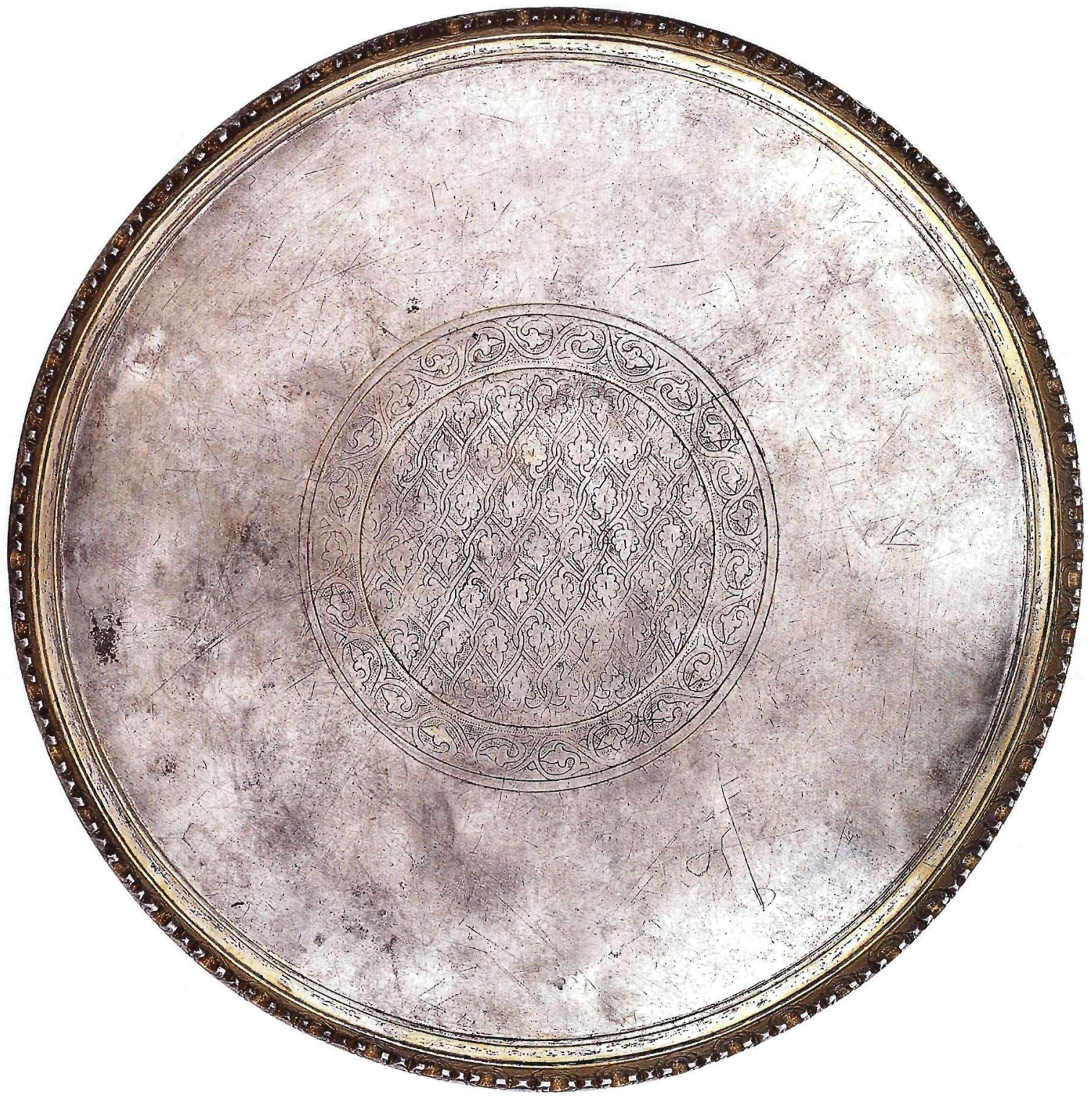

Fig. 2. Footed plate no. 2 with a vegetal ogival lattice. Private collection (photo: Sp. Delivorrias).

variations, the most notable of which is the slightly higher lead content of dish no. 5 (1.15\%). The same composition can be found in silver vessels of the Early Christian era, ${ }^{3}$ and also in those Sasanian and Islamic vessels which have been analysed. ${ }^{4}$ This continuity with earlier practices extends to the techniques of manufacture and ornamentation. The dishes were made by hammering on a lathe, and, in the case of dish no. 7 (see appendix), this exploited the alloy to the full by creating from a relatively small quantity of metal a vessel with very thin walls. ${ }^{5}$
All the dishes display the same decorative layout, with a central medallion normally encircled by a peripheral band and complementary motifs, as is particularly apparent in dishes nos 6-9. An incised preliminary sketch was used for the ornamentation, which the craftsman subsequently followed with his tool, thus often giving a slightly unstable appearance to the contours (fig. 4b). In some cases the lines appear interrupted, evidence of a failure to ensure that each application of the tool follows exactly on the previous one. A variation in the execution can be ob- 
served in dishes nos 1 and 5 , where the motifs are incised by drawing the tool uninterruptedly across the surface of the dish. This technique was used partially on dish no. 1 and on the entire ornamentation of dish no. 5 .

On all the dishes the execution of the motifs is generally schematic; detail is lacking but the motifs stand out against a ring-punched or dot-punched background. The quality of the ornamentation is not consistent: sometimes the engraving is flat (dish no. 2), at others more unstable (as noted in dish no. 4), or less attentive to detail (a comparison of dishes nos 1 and 3 shows that they share a common motif but the execution is uneven in quality). Dishes nos 1 and 5 undoubtedly display the most meticulous, indeed exemplary, execution. The variations in the ornamentation, even where the motifs are similar, suggest either that some dishes were manufactured under greater pressure, or, more probably, that different craftsmen were involved in their production.

Exact parallels for the shape of the dishes with a flat base and shallow sides can be found in late Roman silverware -in certain works from Naissus, for example, one of which has a star motif in the centre. ${ }^{6}$ The shape frequently occurs in 12th century Byzantine ceramic vessels, and examples have been discovered in Corinth, Athens, the Alonnesos shipwreck and elsewhere, though such objects often have a rudimentary base to increase their durability. ${ }^{7}$ The wide circulation of this form of silverware is apparent from its echoes in Islamic art, for although not many dishes made of precious metals have survived, the shape is found in ceramic imitations in 9th-century Samarra moulded ware, 10th-century Samanid slip-painted vessels and a rare Fatimid bronze alloy dish (fig. 7). ${ }^{8}$

Conversely, the two very shallow plates with an ornamental raised rim and a tall foot do not appear to have their origin in late antique models, and the shape, which resembles a modern fruit dish, may be a mediaeval development. The flat base, gently sloping towards the rim can be found in mid- to late 12th century Byzantine ceramics which also have a notched rim, though in these objects the foot tends to be shorter. The remarkable Artukid enamelled bowl has a similar shape, and its external dimensions (diam. $27 \mathrm{~cm}$, height $5 \mathrm{~cm}$ ) are the same as those of plate no. $1 .^{10}$ But the work closest to the footed plates of the treasure is the silver-gilt dish from Muzhi in Siberia, now in the Hermitage (fig. 8)."
It stands on a similar cylindrical foot, the sides terminate in an ornamental raised rim and it has comparable dimensions (diam. $28 \mathrm{~cm}$, height $5.3-6 \mathrm{~cm}$ ). In spite of the fact that few examples of precious utilitarian metalwork survive from the 12th and 13th centuries, the fact that their dimensions are generally similar may be evidence of a certain standardisation in the manufacture of such objects. $^{12}$

\section{Iconographic analysis}

Huntsmen and running animals: The representation on the central medallion of plates nos 1 and 3 (figs 1,3 ) is part of a long tradition going back to late antiquity, when the theme of hunting, a favoured pursuit of the aristocracy, was frequently included in the decoration on mosaic pavements and portable objects of every kind. ${ }^{13}$ In Middle Byzantine art the direct link between hunting scenes and imperial iconography is evidenced by representations of imperial hunts and by explicit literary references. ${ }^{14}$ Middle Byzantine eulogies addressed to the figure of the emperor give constant emphasis to his prowess as a hunter in order to demonstrate his bravery and spiritual power. ${ }^{15}$

Hunting was a theme commonly found in court iconography, but was diffused not merely on precious objects but also on works in mass circulation such as ceramics and sculptures. ${ }^{16}$ Particularly interesting are the depictions of mounted figures on surviving works of Byzantine silverware, such as the similar bowls from Vilgort and Chernigov and the cup in the former Vasilevsky collection (fig. 9). ${ }^{17}$ These share with our plates not only the hunting iconography but also the depiction of nature by means of stylised plants with tendrils terminating in trefoils. The use of these motifs to represent the natural world seems to have been a standard topos in all media of 12 th century art (figs 9-12). ${ }^{18}$

Mounted huntsmen are closely associated with representations of military saints, which also proliferate in the 12 th century, when they are regularly depicted in the iconography of aristocratic equestrian warriors." Striking resemblances can be found in wall paintings, such as the impressive mounted St George at Staraya Ladoga (1167). ${ }^{20}$ The military gear shown on the dishes-ellipsoid shields, greaves, breastplates and short chitons- occurs in numerous portrayals of soldier saints, most notably on 11th and 12th century steatite works. ${ }^{21}$ Yet the most remarkable likenesses are found in an engraved representa- 


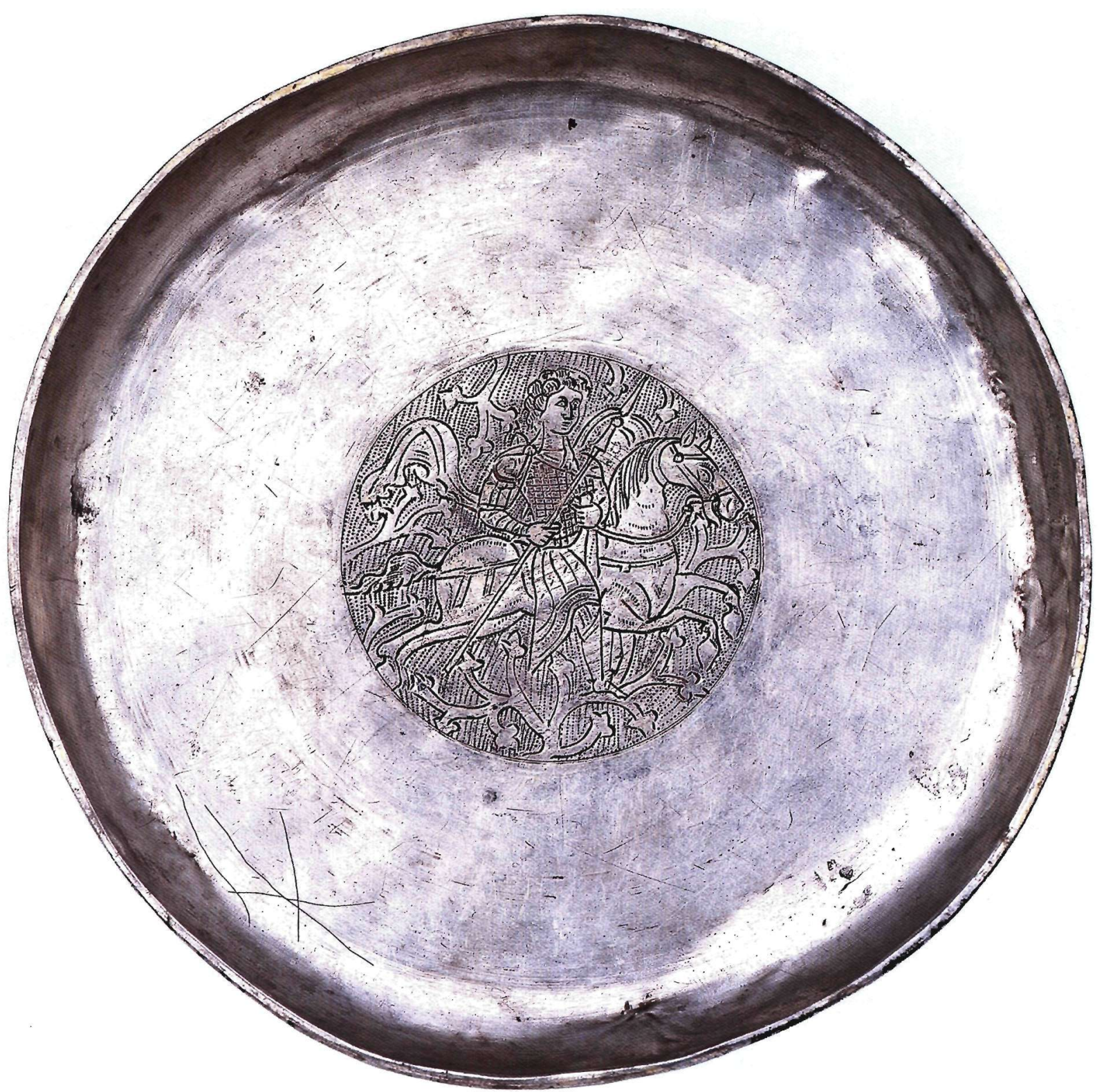

Fig. 3. Dish no. 3 with a mounted huntsman. Private collection (photo: Sp. Delivorrias).

tion on another Middle Byzantine silver vessel, the bowl from Beriozovo, now in the Hermitage (fig. 10). ${ }^{22}$ The exterior of this silver-gilt bowl has rows of convex bosses depicting scenes of court banquet and a female imperial figure in the centre flanked by servants, musicians, acrobats, dancers, animals and birds. The patently secular, court iconography is complemented on the interior by a central medallion with an engraved mounted figure of St George almost identical to that of the hunters on the plates under review. ${ }^{23}$ Indeed those hunters would be exact reproductions of the Beriozovo St George were it not for the absence of the halo and the inscription.

On footed plate no. 1, the representation on the central medallion is supplemented by the band of running animals which encircles the interior just below the rim. Depictions of running animals are common from the late Roman period onwards and they can be interpreted as condensed hunting scenes which may either comple- 

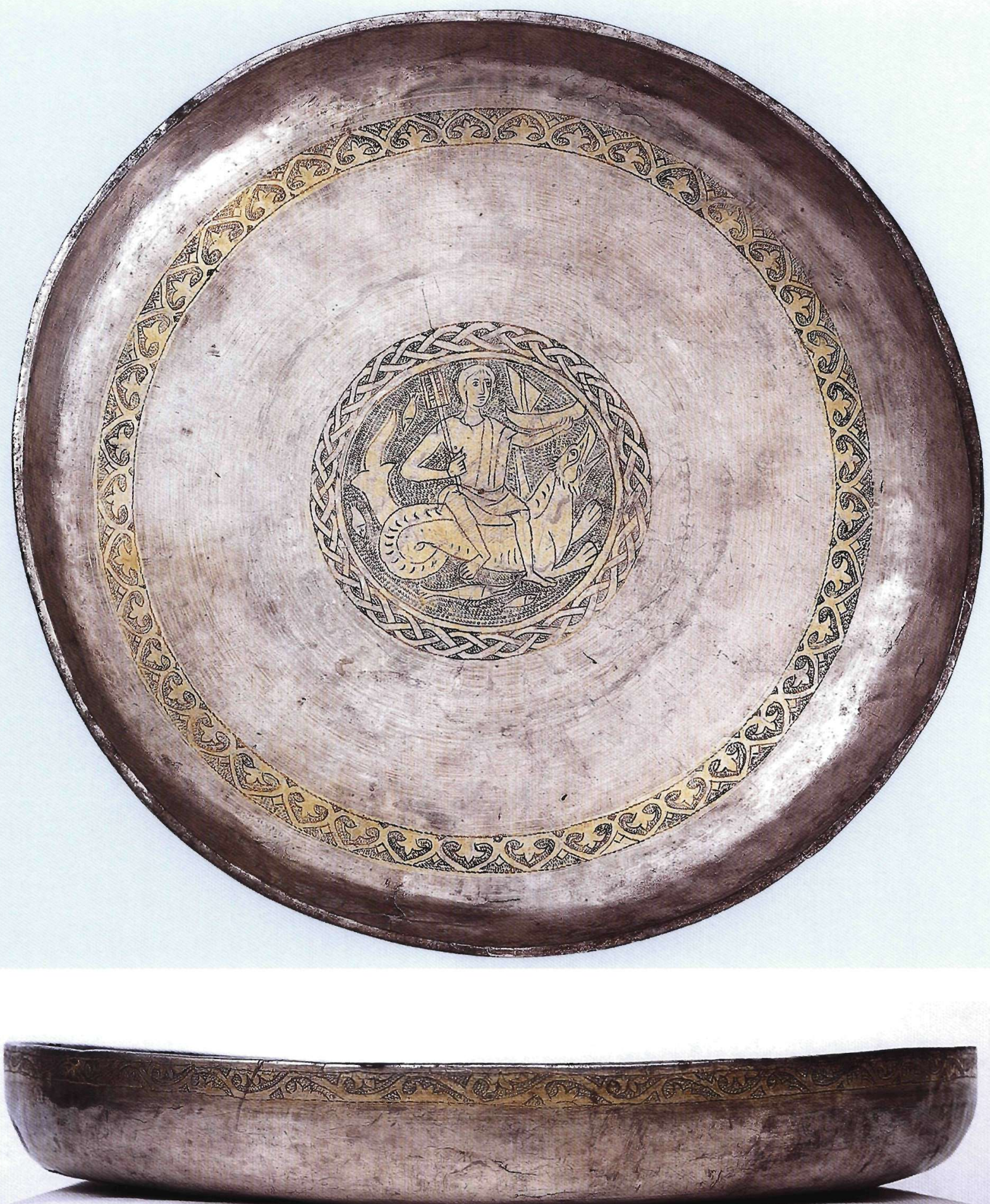

Fig. $4 \mathrm{a}$-b. Dish no. 4 with the personification of the Sea riding on a sea monster. Private collection (photos: Sp. Delivorrias). 


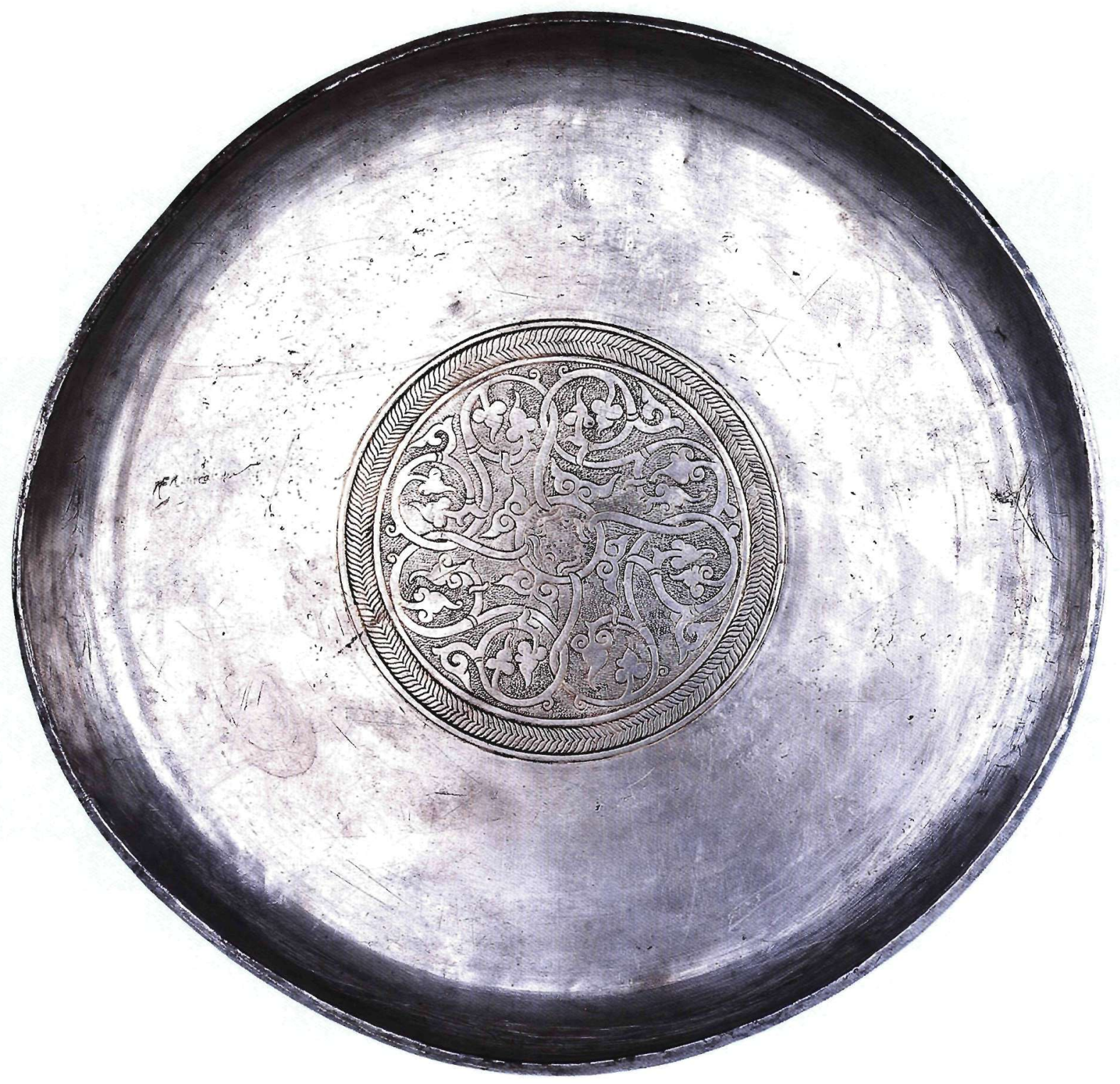

Fig. 5. Dish no. 5 with undulating stems. Private collection (photo: Sp. Delivorrias).

ment or substitute for full depictions of the subject. ${ }^{24}$ In the Middle Byzantine era, running animals are found in all forms of $\operatorname{art}^{25}$, but the closest links occur in the Byzantine silverware mentioned earlier, the cups in the former Vasilevsky collection ${ }^{26}$ (fig. 9) and from Beriozovo ${ }^{27}$ (fig. 10) and the cup cover from Nenetz ${ }^{28}$ (both in Siberia) (fig. 11), while the resemblance of the band of animals on the pan of the Sinai bronze candelabrum is particularly striking (fig. 12). ${ }^{29}$ In all these works the associations go far beyond the iconographic and extend to the style and techniques of the engraved motifs, an indication of their chronological proximity to the plates discussed in this article.

The personification of the Sea: The other interesting figure included in the group of plates is the personification of the Sea on dish no. 4 (fig. 4). Depictions of the Sea as a near-naked woman are found from Greco-Roman antiquity onwards both in literature and in representations on coins, sarcophagi and mosaic pavements, 
ANNA BALLIAN-ANASTASIA DRANDAKI
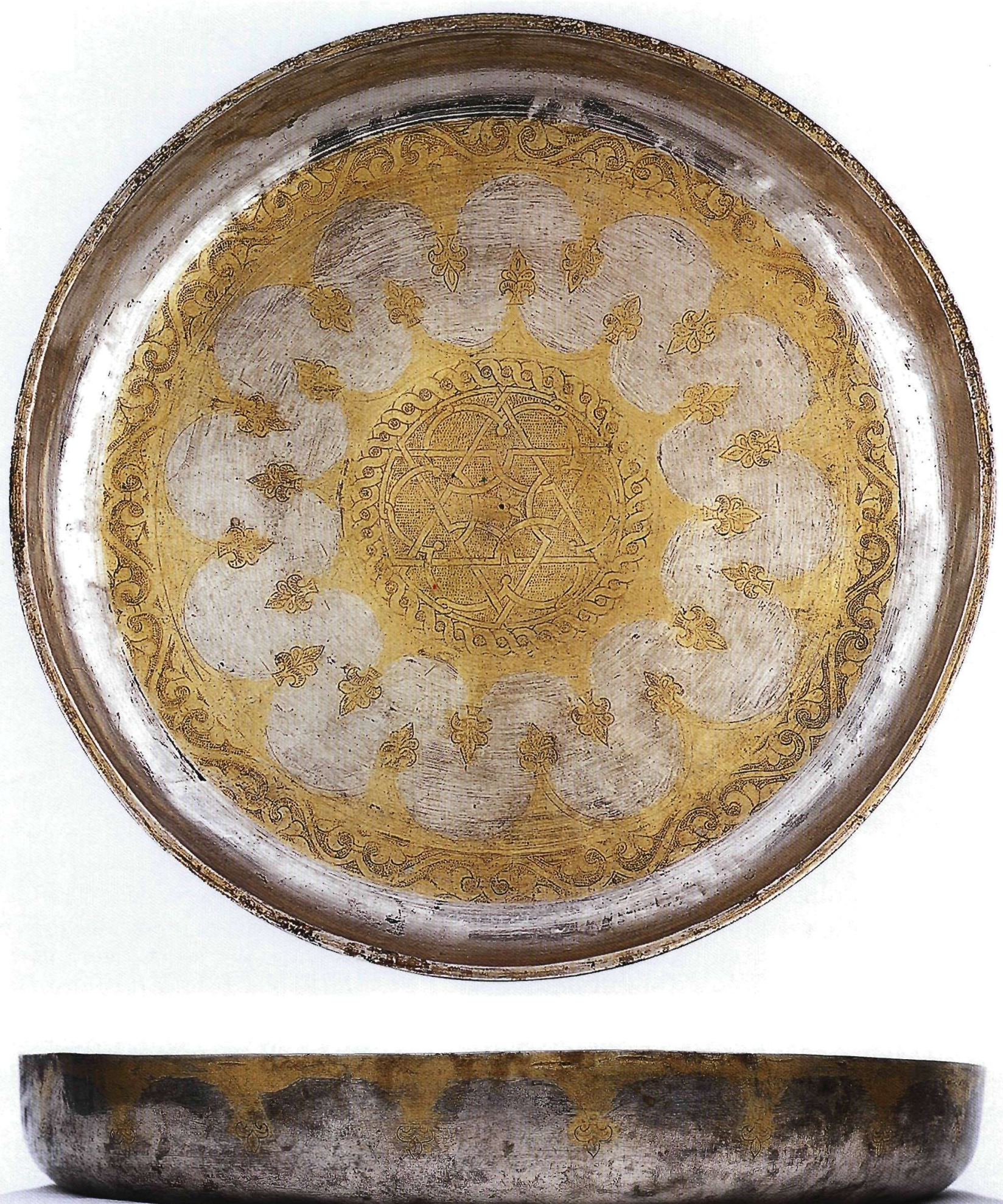

Fig. 6 a-b. Dish no. 6 with a star interlace. Private collection (photos: Sp. Delivorrias). 
most notably perhaps in the church of the Apostles at Madaba in Jordan (578). ${ }^{30}$ In early Christian thematology the Sea is a fundamental part of God's Creation and is normally shown in company with the Earth, the second of the two principal constituents of the Ktesis. ${ }^{31}$ Equally close to the present representation iconographically are the portrayals of Nereids riding sea monsters found, for example, on the medallion of a silver plate in the Galleria Sabauda in Turin (AD 541). ${ }^{32}$

In purely Christian iconography, depictions of the Sea occur in representations of the Baptism, sporadically at first in the 7th and 8th centuries, in the Cappella $\mathrm{Pa}$ latina in the 12 th century, ${ }^{33}$ and finally more frequently from the 13th century onwards. ${ }^{34}$ One of the finest Middle Byzantine representations is to be found in the Paris Psalter, in the depiction of the crossing of the Red Sea (10th century). ${ }^{35}$ In the 11 th century the Sea finds a regular place in representations of the Last Judgment, both in manuscripts ${ }^{36}$ and in wall paintings (e.g. the church of Panaghia Chalkeon in Thessaloniki), ${ }^{37}$ where, in company with the Earth, it renders up the bodies of the dead for judgment. It is similarly depicted in the restored mosaics in Torcello, ${ }^{38}$ in St Nicholas tis Stegis in Kakopetria, Cyprus $^{39}$ and in a 12th-century icon of the Last Judgment in Sinai. ${ }^{40}$ The last of these shows a near-naked woman astride a sea-monster, holding an oar in her right hand and a boat in her left, just as on the dish. ${ }^{41}$ The monster on the icon is also very similar with its diminutive pointed ears, small mane and leonine paws. In depictions of the Second Coming the creature ridden by the Sea spits out the limbs of humans destined to participate in the Last Judgment. The depiction of the gaping-jawed monster on the dish suggests that the craftsman used such a scene as a model, although the features have their direct ancestry in the art of late antiquity. ${ }^{42}$

Middle Byzantine metalware contains a remarkable parallel in the silver-gilt footed plate from Muzhi in Siberia (fig. 8). ${ }^{43}$ The large central medallion with a depiction in relief of the Ascension of Alexander is surrounded by ten representations with cosmological-symbolic content in roundels framed by foliate scrolls. One of these displays a naked representation of the Sea, riding on a sea monster and holding a ship in her right hand and an oar in her left. The beast is similar to that on the dish, but the personification is seated with her back to its head, totally naked but with no indication of sex or other detail of her figure. Interestingly, the ship which she holds contains both rower and steersman.

Aniconic decoration and the Islamic connection: It is the series of dishes with purely aniconic decoration and obvious Islamic associations which give rise to the most ambivalent interpretations. The comparative material to be discussed here will draw on both Byzantine and Islamic art. The purpose is not so much to isolate Byzantine from Islamic stylistic features, but rather to trace the motifs they have in common, establishing the extent of their dissemination, and -in so far as this is possibleidentifying the specific type of objects which formed the vehicles through which they were circulated.

The footed plate no. 2 (fig. 2) is decorated with an ogival vegetal lattice framed above and below by heart shapes. Rows of alternating heart shapes enclosing leaves with a central hatching are almost a hallmark of Byzantine decoration but are an equally common motif in Islamic art. Examples of the latter are a ceramic sgraffiato bowl, of a type dated variously to the 10th and the 11th century, ${ }^{44}$ a Fatimid lustre-painted vase, ${ }^{45}$ a cast bronze mortar from eastern Iran, ${ }^{46}$ and a silver flask from the Harari treasure, attributed to 11th century Northern Iran. ${ }^{47}$ Comparable Byzantine examples with pointed multi-lobed leaves can be seen in the heading of a manuscript of 1140 in the Escorial, ${ }^{48}$ on the fragment of a champlevé ceramic, ${ }^{4 \%}$ and on the silver bowl cover from Nenetz with representations of musicians and acrobats (fig. 11). ${ }^{50}$ The ogival layout of the decoration occurs in the headpieces of manuscripts (fig. 13), which in the 11 th and especially the 12 th centuries display motifs enclosed in heart shapes pointing alternatively upwards and downwards. ${ }^{51}$ This ogival design is not unknown in 12th-century wall painting, and can be found in the Petritzos monastery in Bachkovo, Bulgaria, and Cefalu cathedral in Sicily. . $^{52}$

Dish no. 5 of the treasure has foliate palmettes on the central medallion and exceptionally intricate incised workmanship (fig. 5). The meticulous herringbone pattern surrounding the medallion and the ribbons tied to the stalks at points where they divide produce a striking late antique effect which is heightened by the otherwise undecorated surface of the dish.

At first sight the ornamentation has no direct parallels in silverware, Byzantine or Islamic. A meticulous exami- 


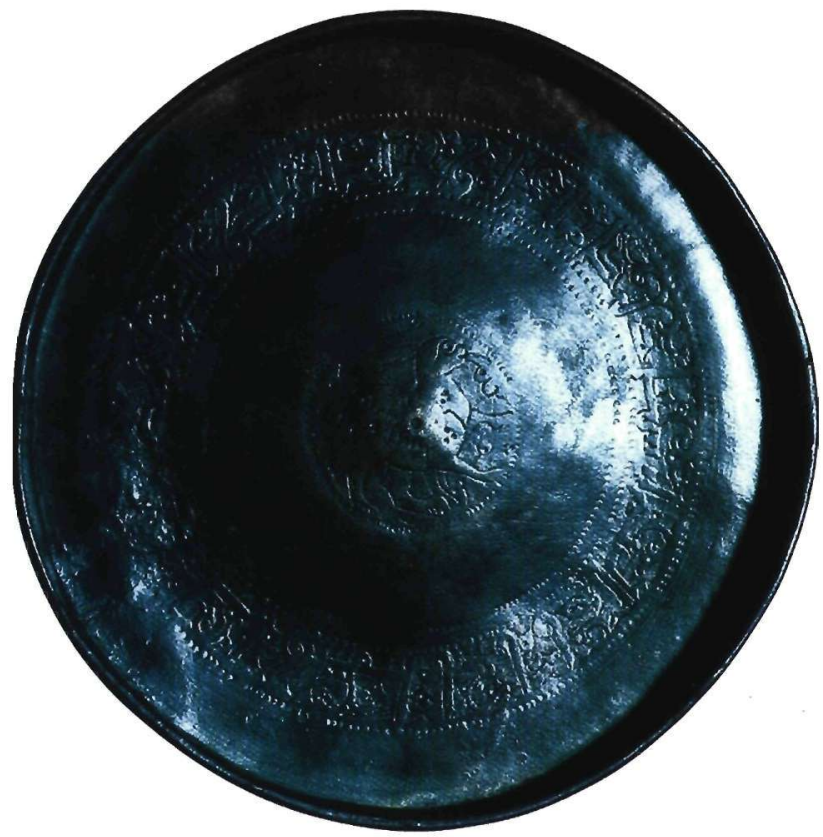

Fig. 7. Fatimid bronze dish with a rabbit and an inscription band, 11 th-12th century. Paris, Louvre Museum no. AA. 275 (photo: courtesy of the Louvre Museum).

nation of Central Asian silverware-notably that from 8th and 9th-century Sogdia, which post-dates the Islamic conquest but could still use Sasanian silverware as its modelsindicates a different use of late antique decoration, with an emphasis on richer ornamentation and on larger-scale vegetation, which is often rendered naturalistically. ${ }^{53}$

The closest examples of bowls and plates with scrolling tendrils on the base are actually found in ceramics, both Byzantine and Islamic. To begin with the Islamic versions, Samanid slip painted pottery attributed to 10th century Nishapur and Samarkand is believed to reflect the ornamentation on now lost contemporary silverware which continues the tradition of Sogdian silver. ${ }^{54}$ This ceramic ware displays the most striking resemblances to the silver dish, with four scrolling tendrils sprouting from a circle (fig. 14). ${ }^{55}$ There is one important difference, in that the palmettes of dish no. 5 have a foliate design, with curved, pointed ends, while Samanid and earlier Sogdian palmettes are round, many-petalled and have a floral origin. ${ }^{56}$

The mid-12th century Byzantine shipwreck at Alonnesos (fig. 15) and the excavations at Corinth and Athens have produced numerous examples of sgraffiato and champlevé ceramics which display a continuing use of designs with palmettes as central motifs on bowls and plates. The foliage has the same linear character and is displayed against a scaled background which imitates the punched ground of silverware. ${ }^{57}$ All this suggests two possible interpretations for the provenance of dish no. 5. The first is that the dish predates the remainder of the treasure and is probably a 10th-century work from Eastern Iran. Alternatively, the dish is Byzantine and more or less contemporary with the rest of the treasure but reproduces models from 10th-century silverware -an instance of a return to earlier prototypes which is familiar in Byzantine art, but would be unusual in the art of Islam, which had from the 11 th century introduced the arabesque in its decorative vocabulary. ${ }^{58}$

The four dishes of the treasure, nos 6 to 9 (fig. 6), share the same design of radiating garlands and geometrical star-shaped interlace, the latter deriving from the complex geometrical interlace found in Islamic ornamentation from early times. ${ }^{59}$

The closest parallels to our silver dishes can be found in metalwork of Eastern Iran dated to the 12th and early 13 th century. The main decorative feature on a series of bronze dishes is the central roundel containing a sixpointed interlace framed by rayed garlands and inscribed bands (fig. 16). ${ }^{60}$ Eastern Iran was the birthplace of Islamic inlaid metalwork, though production spread to Northern Mesopotamia and Syria: this form of metalwork is relevant here because, as we shall see, it seems to have been known to the Byzantines and the other Christians of the Near East.

An example of an exactly similar star-shaped interlace with the characteristic indentation in the middle of its sides occurs in the frontispiece of a 12th-13th century Syriac manuscript $t^{61}$ and also in the interior of a western silver standing cup, housed in the monastery of St Maurice d'Agaune in Switzerland and attributed by Charles Oman to Norman Sicily. ${ }^{62}$ Boris Marshak, taking the argument further, considers that the combination of the western shape and the orientalising decoration indicates a place of manufacture where western and Islamic influences could co-exist side by side, such as the Crusader states of the Near East, as well as Sicily. ${ }^{63}$

The twelve-pointed garlands on the four dishes of the treasure (nos 6-9) are more closely associated with a large brass 13 th-century bowl from Northern Syria or 

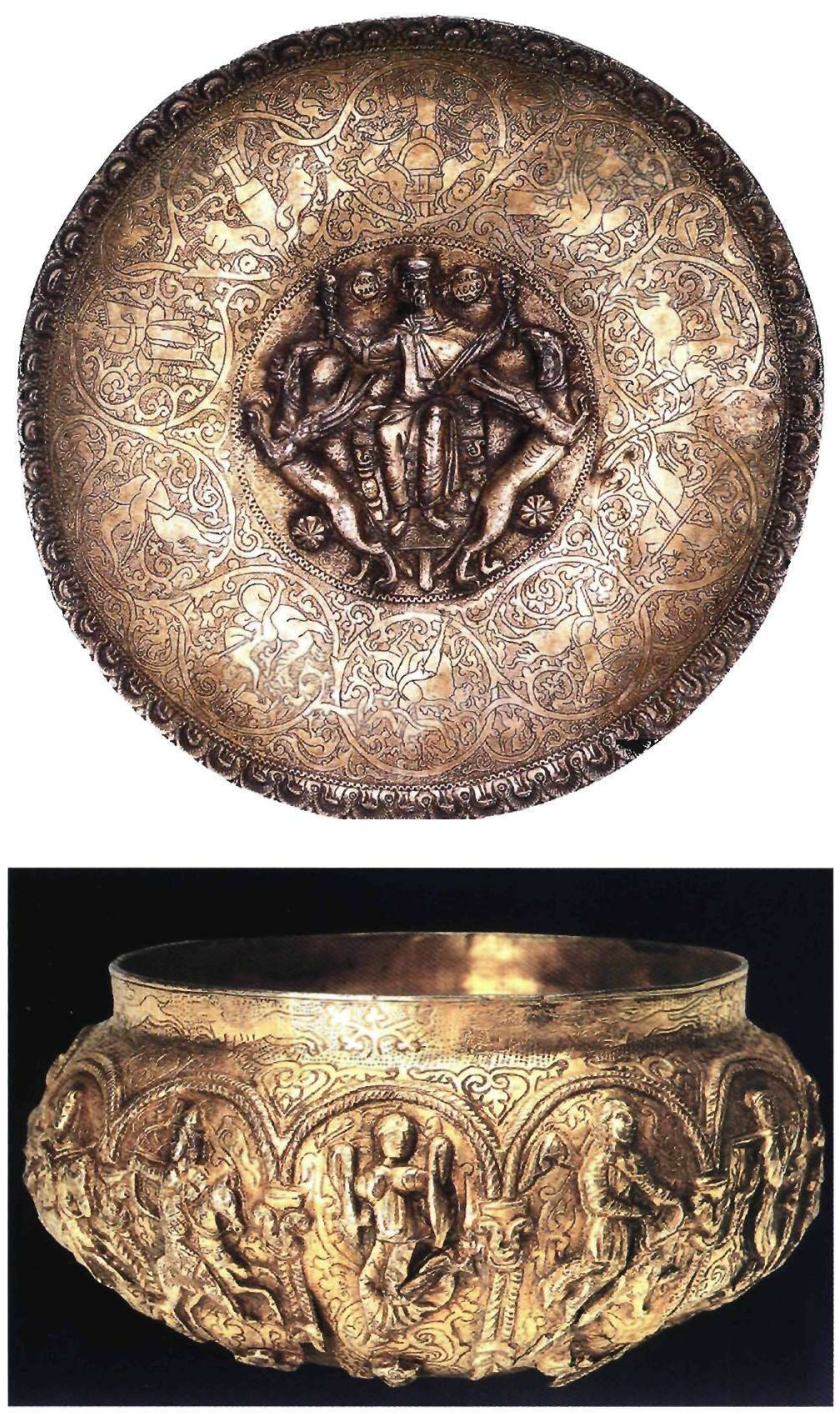

Fig. 8. Footed plate with the Ascension of Alexander the Great from Muzhi, Siberia, early 13th century (after: Glory of Byzantium 1997, 400 no. 267).

Fig. 9. Bowl with courtly scenes and mounted soldiers from the Vasilevsky collection, 12th century. Saint Petesburg, The

State Hermitage Museum no. $\omega 72$ (after: Byzantium: An Oecumenical Empire [Athens 2002] 47 no. 7).

the Jazira with inlaid silver decoration. Here the garlands are twelve-pointed and bear large rounded palmettes in a reciprocal arrangement similar to that of the four dishes. ${ }^{64}$ Conversely, the Byzantine decorative repertoire is responsible for the design of the band on the base of our dishes with S-shaped tendrils terminating in two halfpalmettes. An identical motif is found on a 12 th-century incense burner in the form of a domed building, now in St Mark's treasury and attributed to a Constantinopolitan workshop. ${ }^{65}$

The imitation of a base metal Islamic model by a silver Byzantine vessel is theoretically improbable and the reverse of what would normally be expected, since the established hierarchical order starts with objects made of precious materials and descends to cheaper materials such as copper alloy and finally to ceramics. Yet in the Islamic world inlaid metalwork - the principal innovation of the 12th century- became a socially and aesthetically acceptable substitute for precious metal objects. ${ }^{66}$ The impact of these novel inlaid vessels would certainly have been felt in Byzantium, where they may have arrived by way of Northern Syria and the Jazira -the provenance of the dish mentioned above- the Sultanate of Rum, or the sea routes and ports of the Syrian coast. And even if at first glance these theories appear somewhat tenuous, we must remember that they are supported by the very substantial number of surviving Byzantine sgraffiato ware which are clearly influenced by Islamic metalwork. ${ }^{67}$

Indeed, the above mentioned group of Iranian bronze dishes (fig. 16) with star-shaped interlace in their centres, is also decorated with animals, birds and concentric zones with inscriptions (fig. 17), ${ }^{68}$ and may be considered the actual model for a certain class of Byzantine sgraffiato ceramics (figs 18, 19). ${ }^{9}$ Corroborative features include the pseudo-Kufic inscriptions and the roundels with stylised palmettes or animals which interrupt the inscribed bands and do not occur in this form in Islamic ceramics. Corinthian sgraffiato ceramics of this type, which have the closest links with Islamic metalware, date from between the second quarter of the 12 th century and $1200 .^{70}$ This suggests that 12 th century Islamic metalwork was circulating in Byzantine territories -specifically mainland Greece-, not merely in frontier areas or Crusader states, while the numerous Islamic ceramic fragments found in Corinth indicate the existence of commercial relationships with Egypt and Syria before the mid-12th century. ${ }^{71}$

As is clear from the above discussion the three dishes with human figures have particularly strong links with Byzantine art, 12th century metalwork in particular, while the aniconic ornamentation of the other six contain resemblances to Byzantine and Islamic works of the same period. 

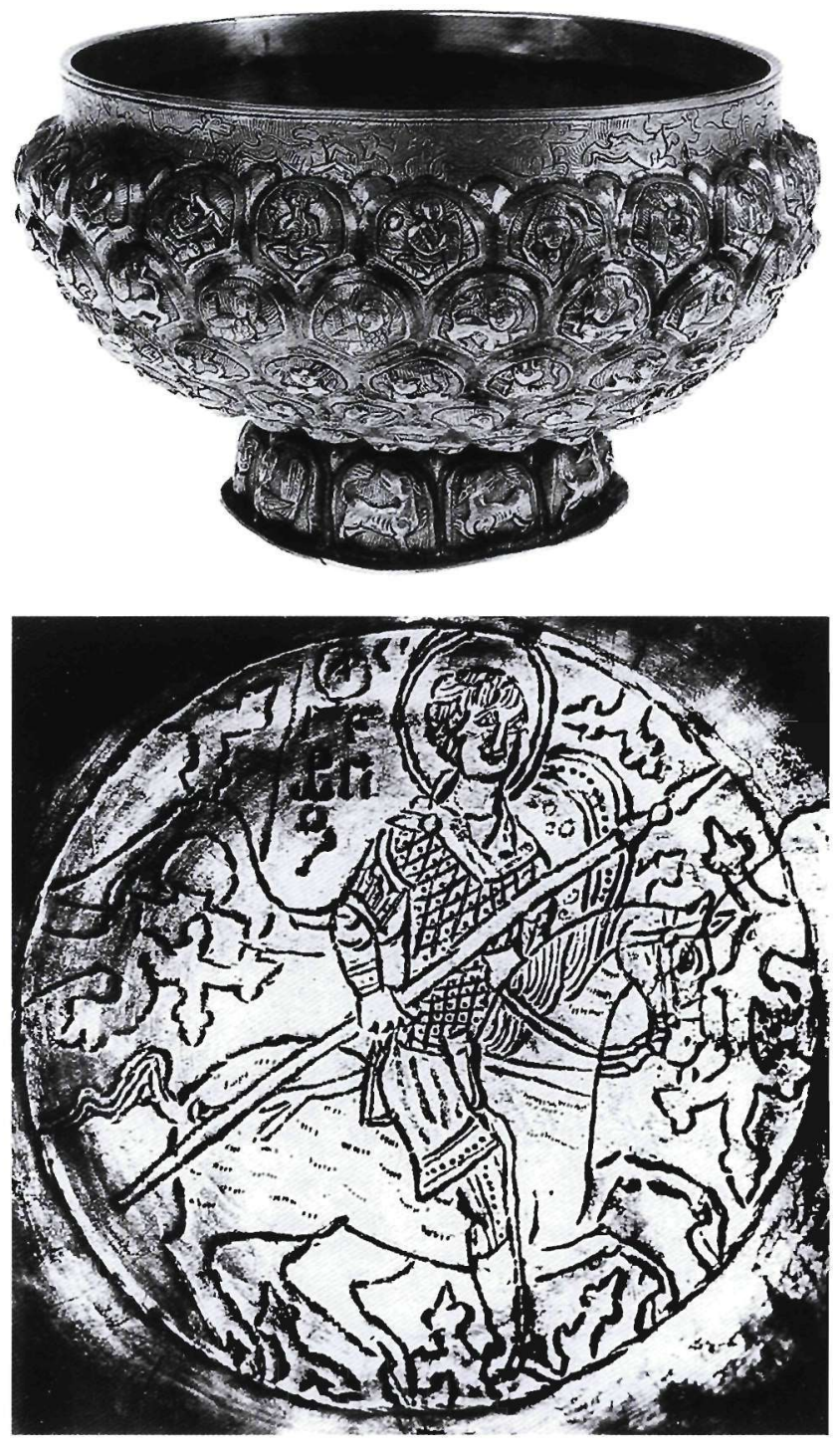

Fig. 10 a-b. Bowl with courtly scenes and the mounted figure of Saint George in the inside, from Beriozovo, 12th century. Saint Petersburg, The State Hermitage Museum no. $\omega 3$ (photo: courtesy of The State Hermitage Museum).

\section{The Izgirli Treasure}

The nine dishes of the treasure have direct links with three silver plates in the Cabinet des Médailles in Paris, whose dimensions, shape, technique and iconography are not merely comparable but nearly identical with the vessels studied in this article (figs 20-21). ${ }^{72}$ They are familiar in the bibliography as the Izgirli or the Tatar Pazarcik treasure, after the Bulgarian village near where they were found in 1903 and its nearby town. This makes a com- parative study of the two groups of objects highly desirable, as they not only belong to a common tradition and share the same provenance, but are probably made by the same or by closely related workshops; it is even possible that all the vessels originally formed a single group, though this cannot be proved. ${ }^{73}$

Two of the Izgirli plates are footed and bear identical decoration (fig. 20), while the third and largest dish belongs to the type with a flat base and low rising sides (fig. 21). Although the three plates from Izgirli have not been subjected to technical analysis, visual observation indicates that there are considerable discrepancies in the quality of the execution. The decoration on all three vessels was made by engraving tool, but that on the two similar footed plates is less meticulous, indeed somewhat unsteady, most obviously on the contours and the central rosettes. The third and largest dish is much more carefully worked, and the ornamentation is supplemented by zig-zag engraved lacework around the medallion and the bands, which is not found on any other plate in the group.

On footed plate no. 1 (fig. 1) and on the three Izgirli plates the bands of running animals, though directly comparable in subject and execution, are not identical. The most obvious variation is found on the large Izgirli dish (fig. 21), where the animals are portrayed on vegetal scrolls, in a configuration known as animated or inhabited scrolls. Such scrolls are found in Middle Byzantine art both in manuscript illumination and in sculpted works and ceramics. ${ }^{74}$ Similar motifs occur in illustrations in 12th-century Romanesque and Crusader manuscripts ${ }^{75}$ and in works of minor $\operatorname{arts}^{76}$ and sculptures from the same environment, such as the celebrated east lintel from the south façade of the Holy Sepulchre, which is attributed to a local workshop of the second half of the 12th century. ${ }^{77}$ In Crusader and Romanesque works the figures of men and animals are intertwined with the scrolls as if they were struggling to escape from them, and sometimes seated on top of them. ${ }^{78}$ In such cases figures and scrolls exist on an equal plane, but on the Izgirli dish the plant motif merely exists as a ground for the figures engraved above.

This use of undulating scrolls as a background for running animals is common in 11th-12th century Islamic works, such as a bronze ewer and a bucket from eastern Iran, ${ }^{79}$ and the group of bronze dishes mentioned above (fig. 16).$^{80}$ Together with the geometrical motif of the cen- 


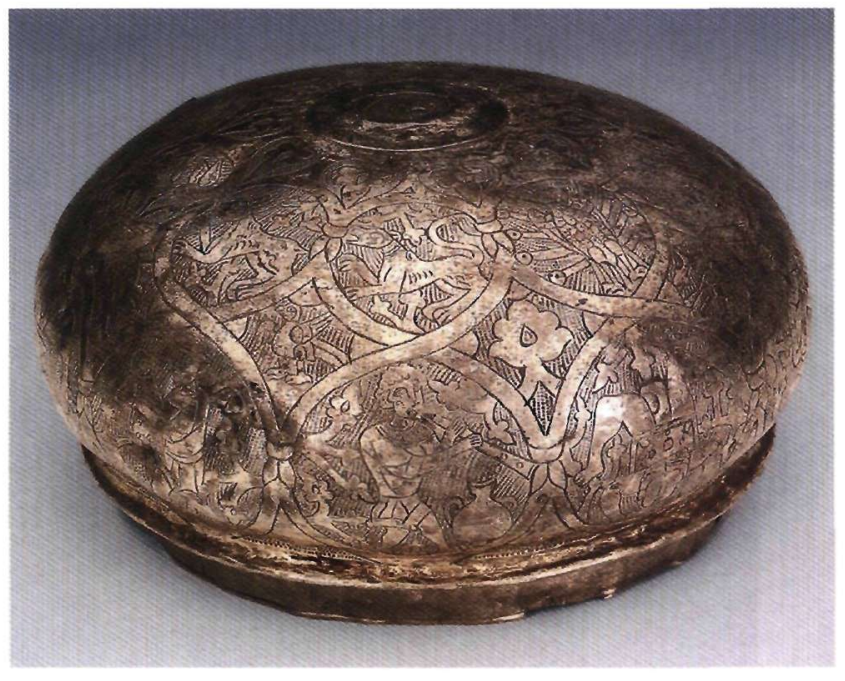

Fig. 11. Lid of a bowl with courtly scenes from Nenets, Siberia, 12th century. The State Hermitage no.1193 (after: D. Papanikola-Bakirtzi [ed.] Everyday Life in Byzantium [Athens 2002] 199 no. 222).

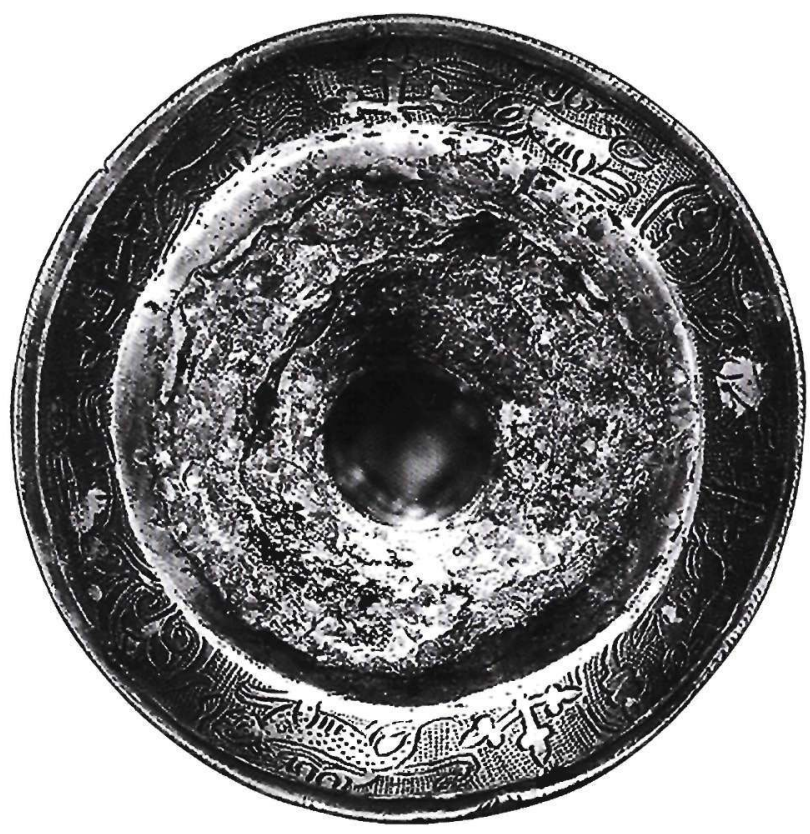

Fig. 12. Bronze candelabrum from Saint Catherine's monastery, Sinai, Egypt, 12th century (after: L. Bouras, Three Byzantine Bronze Candelabra from the Grand Lavra Monastery and Saint Catherine's Monastery in Sinai, DChAE 15 [1989-1990] 24 fig. 15).

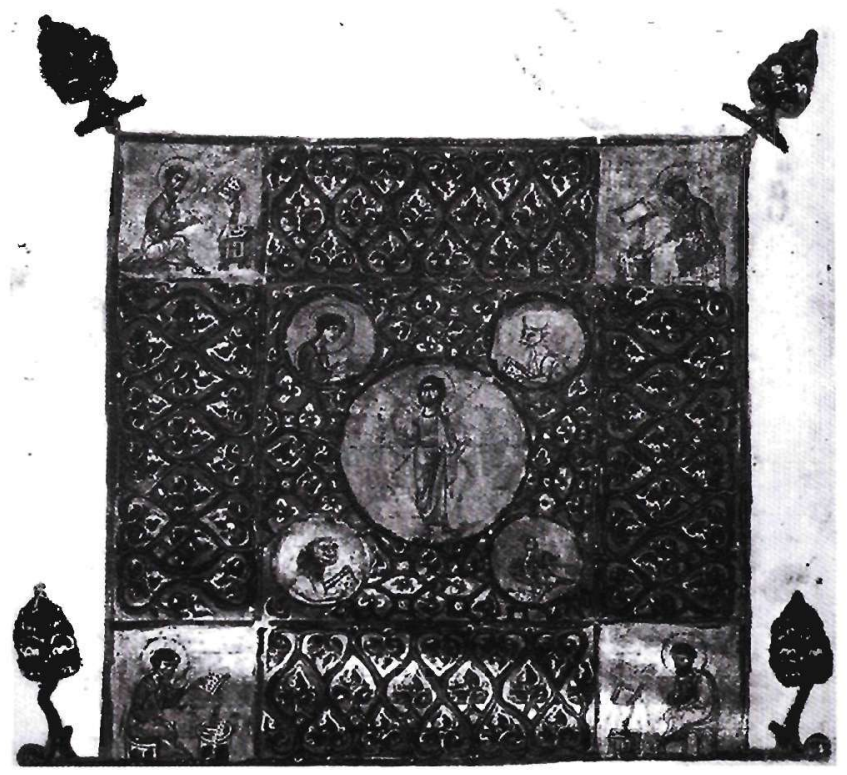

Fig. 13. Headpiece from a manuscript of the Gospel, last quarter of 11 th century. Oxford, Clarke 10, fol. $2^{\mathrm{v}}$ (after: G. Galavaris, The Illustrations of the Prefaces in Byzantine Gospels [Vienna 1979] fig. 53).

tral medallion, this constitutes a basic link with similar Islamic works. Two details are different, however. The Iranian works commonly include among the running animals Afghan hunting dogs with strikingly long muzzles (Salukis) which are not depicted on the Izgirli dish, ${ }^{81}$ while the outer band of the Izgirli dish displays a naked human figure swimming among the vegetation, which is unprecedented in Islamic art. Conversely, the representation of naked humans is a familiar theme in Crusader art $\mathrm{t}^{82}$ -for example on the lintel of the Holy Sepulchre referred to above- and in Byzantine secular iconography. Typical of the latter are the numerous depictions of nude figures on Middle Byzantine ivory caskets. ${ }^{83}$ The popularity of such portrayals in contemporary secular art produced a reaction from the Church, evident in the well-known passage where Theodore Balsamon, commenting on Canon 100 of the Synod of 692, denounces his contemporaries for the practice of decorating their houses and their possessions with naked figures. ${ }^{84}$ In spite of this, such figures were not unknown even in the religious iconography of Byzantium, most commonly in scenes of the Baptism of the followers of John the Baptist ${ }^{85}$ but also in a more obviously decorative context, the initial letters of manu- 


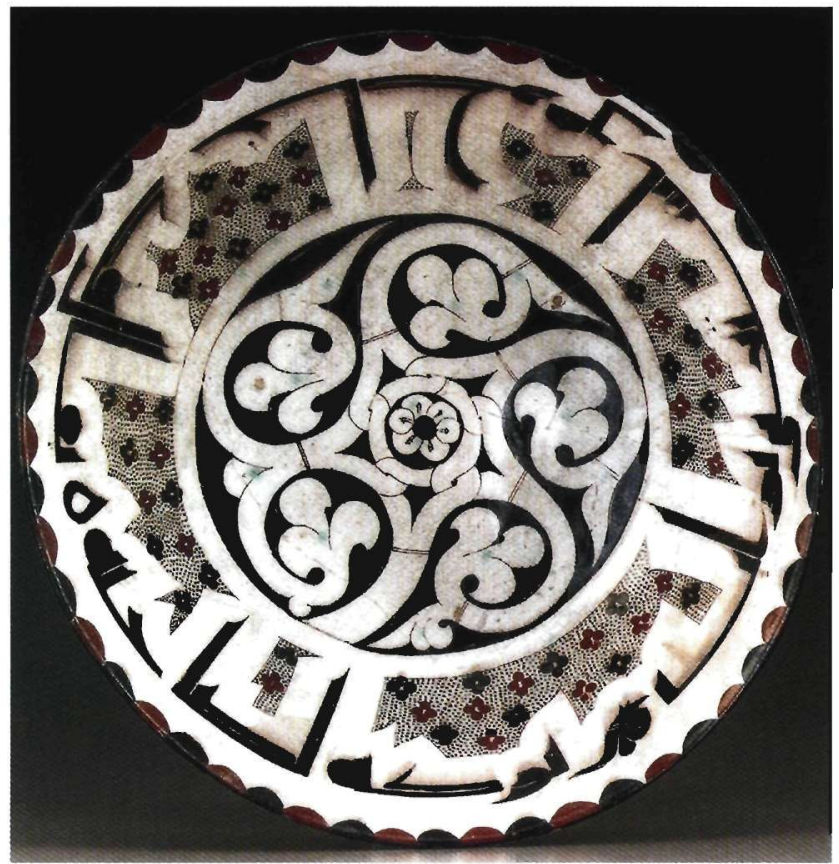

Fig. 14. Eastern Persian slip-painted bowl with undulating stems and inscriptions, 10th century. Washington, Freer

Gallery of Art (after: R. Ettingausen, O. Grabar, M. Jenkins-Madina, Islamic Art and Architecture 650-1250

[New Haven-London 2001] 120 fig. 189).

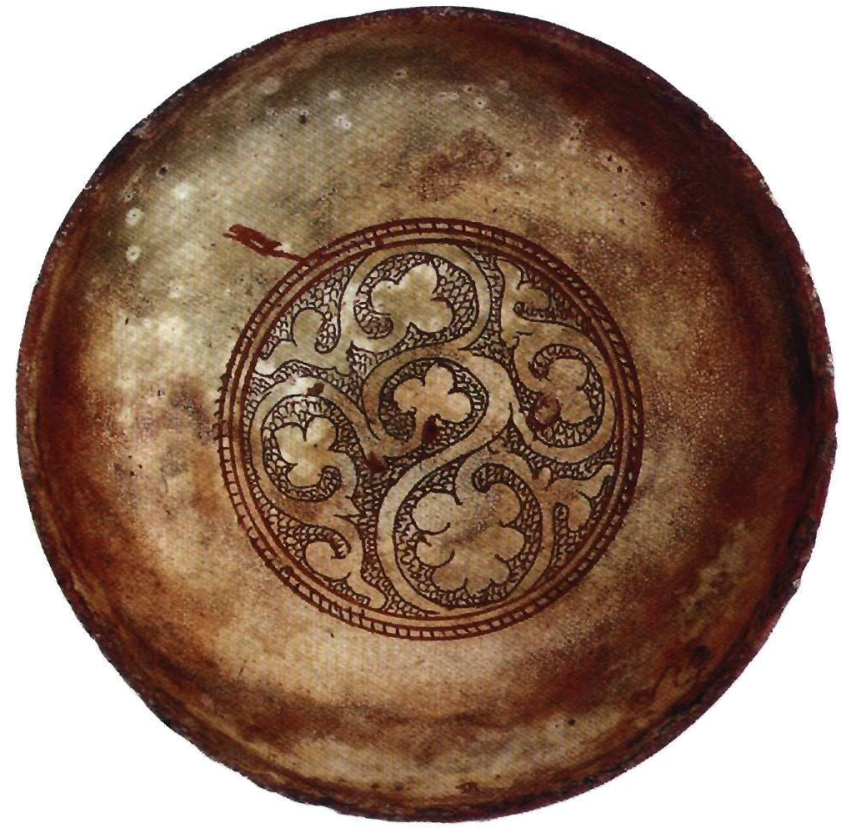

Fig. 15. Sgraffiato bowl with undulating stems from the Alonnesos shipwreck, mid-12th century. Nea Achialos Archeological Depot, no. N.A. 2 (683) (after: PapanikolaBakirtzi 1999, 138 no. 155). scripts. ${ }^{86} \mathrm{~A}$ similarly nude figure is represented on another Middle Byzantine silver vessel, the 11th-12th century bowl of Theodore Tourkelis, now in the Hermitage. ${ }^{87}$

Two further details that require interpretation are the fish which fill the interstices of the star interlace on the Izgirli dish and the twelve-rayed garlands on dishes nos 6-9 of the treasure. Both point to a cosmological symbolism inherited from Late Antiquity which is found in both the Byzantine and the Islamic world, and originates in the association of circular surfaces with the Dome of Heaven. In Islamic bowls and dishes this symbolism is explicit, with the inclusion of the twelve astrological signs surrounding the sun and whorling fishes and fantastic animals. ${ }^{88}$ In Byzantine art it may take on religious overtones, as in the representation of the Ascension at Kurbinovo (1192) in which Christ is shown at the centre of the circular glory, which is occupied by fishes and fantastic beasts. ${ }^{89}$ In Byzantine secular art the silver bowl from Muzhi (fig. 8) with the Ascension of Alexander displays the familiar solar associations, while in literature a golden bowl depicting the feats of Manuel I Komnenos is likened to the orb of the earth. ${ }^{90}$

The background to the Izgirli Treasure has preoccupied and divided scholars, some of whom attribute it to an Islamic and others to a Byzantine environment. The various theories which have been expressed, and which are summarised below, indicate the general problems involved in studying the common ornamental vocabulary which developed in the Eastern Mediterranean and was articulated in 11th and especially 12th-century objects.

The Izgirli Treasure was published in 1903 by the French consul in Plovdiv (Philippopolis), M. Degrand, who wrote a detailed report on these major new Byzantine finds. ${ }^{91}$ Consequently the treasure was purchased by Gustave Schlumberger who donated it to the Cabinet des Médailles in 1929. As Schlumberger considered that the plates did not fall within his sphere of expertise he invited Gaston Migeon, his distinguished colleague in Islamic Art, to publish them. Migeon's article in the periodical Syria for 1922 ascribes the plates to the hoards of silver 


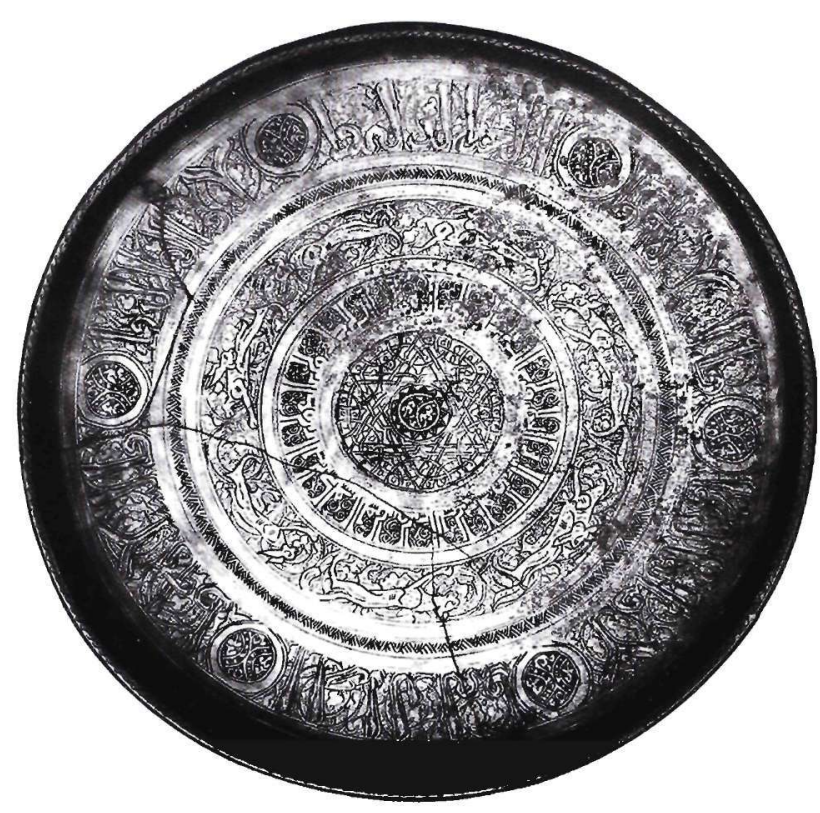

Fig. 16. Eastern Persian bronze dish with a star interlace and running animals, early 13 th century. London, Victoria and Albert Museum (after: A. S. Melikian-Chirvani, Islamic

Metalwork from the Iranian World 8th-18th Centuries

[London 1982] 97 no. 27).

objects of eastern provenance which demonstrate the in fluence of Sasanian and early Islamic art. ${ }^{22}$ These hoards, which had been discovered in Siberia, Hungary and Scandinavia, were assembled by peoples from the North who followed the river trade routes, bartering furs and slaves in exchange for coins and precious objects mainly in the frontier areas of north-east Iran, the Caucasus and the Black Sea. The publication of the Viking treasures in the Stockholm Museum a few years before Migeon's article had brought to light the phenomenon of the transportation of silverware from Asia to Europe, and Migeon accordingly had no hesitation in declaring that the Izgirli plates were manufactured between the 9th and 11th centuries in the spirit of early Islamic art and brought to Bulgaria from the Caucasus and Armenia.

Between the 1920s and the 1970s there was no systematic study or publication of the Izgirli Treasure, although it was mentioned in descriptions of mediaeval hoards discovered in Bulgaria, and by A. Grabar who referred to it in connection with Byzantine secular silverware. ${ }^{93}$ In

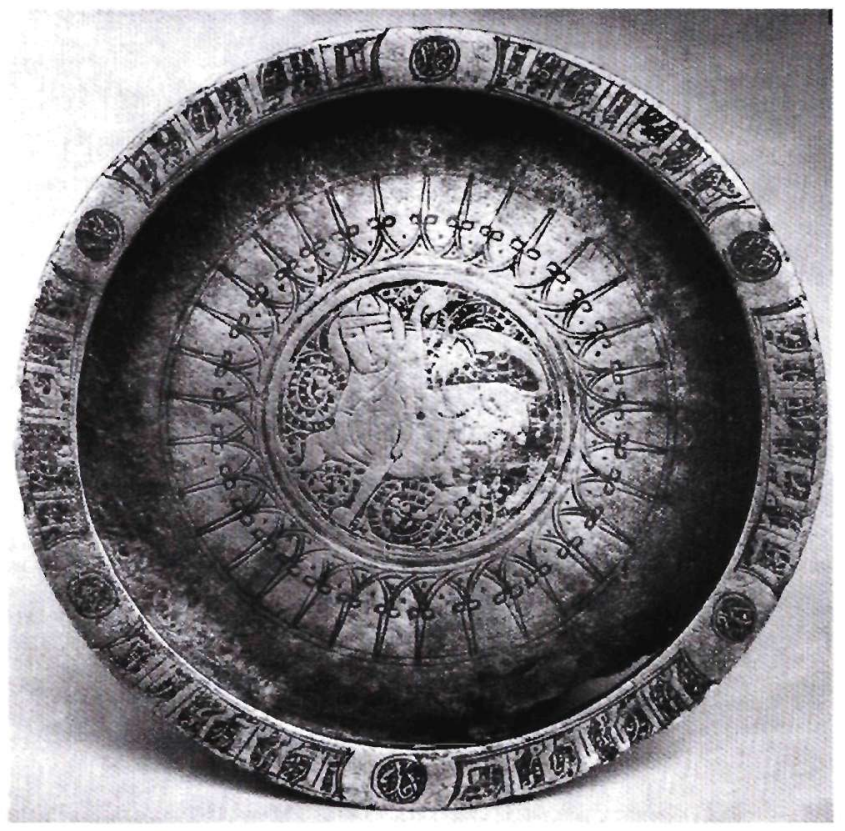

Fig. 17. Eastern Persian bronze dish with a fantastic animal, second half of 12 th - early 13 th century. London,

Victoria and Albert Museum (after: A. S. Melikian-

Chirvani, Islamic Metalwork from the Iranian World 8th18th Centuries [London 1982] 105 no. 36).

1973, however, one only of the three objects in the hoard, the large dish (fig. 21), was published by A. S. MelikianChirvani, who attributed it to Khurasan in Eastern Iran, and dated it to the 11th century, apparently ignoring the articles of Degrand and Migeon. ${ }^{94}$ In the catalogue of a large exhibition of Islamic art held in London in 1976, James Allan gives the same dating to that dish, but he notes that it was part of the Izgirli hoard and that its stylistic analogies with Samarkand ceramics make a provenance in Transoxiana more likely than Khurasan. ${ }^{95}$ Both writers emphasise the oddity in the context of Islamic art of the figure of the nude swimmer on the outer band of the dish. From that time until the present day this same dish has been continuously mentioned in publications relating to 10th-11th century Islamic metalwork from Khurasan and Transoxiana. ${ }^{96}$

It was at roughly the same time as the mounting of the Arts of Islam exhibition in London that a series of studies began to be written by Russian scholars, who exploited the accessibility to them of virtually all the 'orientalising' 


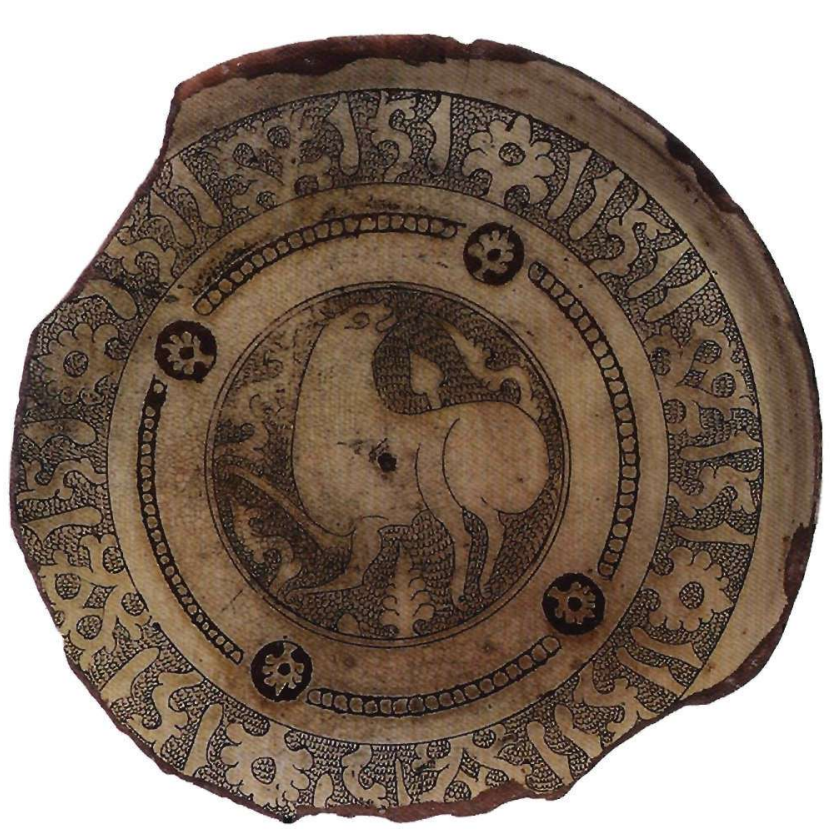

Fig. 18. Sgraffiato dish with a lioness from the Alonnesos shipwreck, mid-12th century. Nea Anchialos, Archeological Depot no. N.A. 33 (1403) (after: Papanikola-Bakirtzi 1999, 131 no. 143).

silver hoards discovered in the territories of the former Soviet Union. The first and most significant of these was a monograph by V. P. Darkevich, who in 1975 made a detailed study of all three Izgirli objects, ascribing them to the secular court silverware of 12th-century Byzantium. He notes the mix of 'classical' and 'orientalising' features which could only be attributed to the melting-pot of Constantinople. ${ }^{97}$ In 1978 A. Bank included the Izgirli hoard among 12th century Byzantine objects of provincial -specifically Bulgarian- workmanship. ${ }^{98}$ In 1982 Boris Marshak, in his article on Crusader metalwork, singled out the flat dish, associated it with similarly ornamented standing cups from Western Europe and declared that the fusion of Islamic and western influences suggests the environment of Near East Christian territories such as Crusader Edessa and Armenian Cilicia." It was presumably this hesitant attribution of the Izgirli dishes to the Byzantine, Islamic or Crusader world which led to them being excluded from the 1992 Paris exhibition on Byzantium, which consisted of objects from French museums only. ${ }^{100}$

Our existing knowledge of the Izgirli treasure has been greatly enriched by the appearance on the scene of the

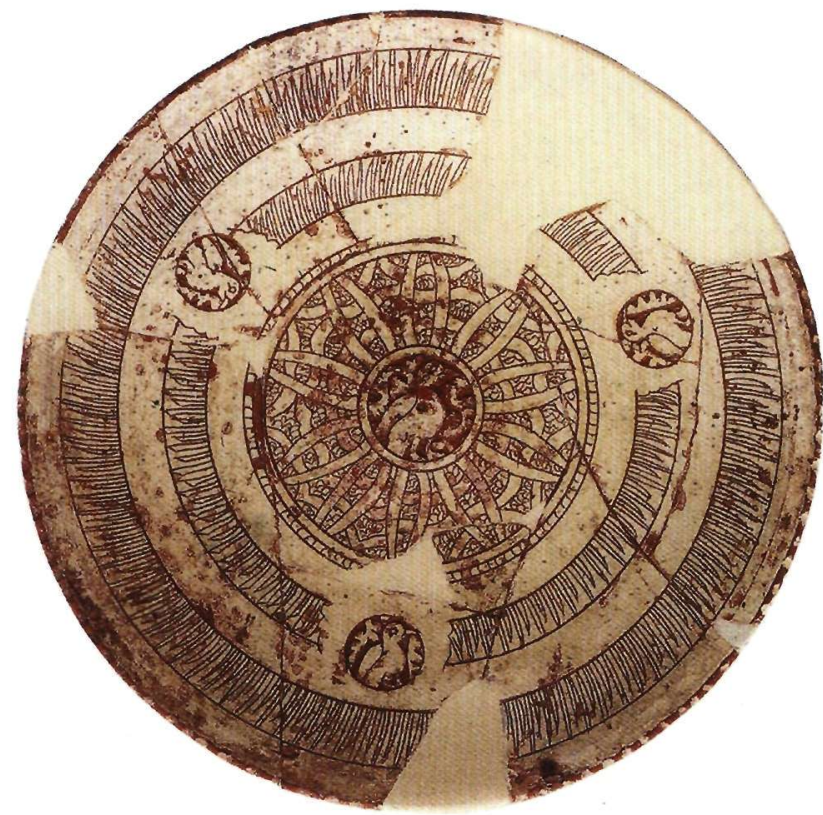

Fig. 19. Sgraffiato dish with a star interlace and pseudo Kufic inscriptions from Corinth, 1170-1200. Ancient Corinth, Archeological Museum, no. C-1937-0866 (after: Papanikola-Bakirtzi 1999, 45 no. 30).

comparable dishes in the group discussed in this article. In this connection the evidence of the French consul in Plovdiv, M. Degrand, may be proved particularly significant in establishing their cultural background and date. ${ }^{101}$ According to his account, he was originally shown 150 gold coins of three Komnenoi -Alexios I, John II and Manuel I- which had recently been found near Tatar Pazarcik, outside Izgirli. The local police chief subsequently confirmed the discovery of a large hoard of coins in the area, amounting to 25 kilos of gold. Many of these were melted down and sold in the markets of Tatar Pazarcik and Plovdiv, while according to a local policeman around 250 coins were dispatched to the museum in Sofia. ${ }^{102}$

Other precious objects were found in addition to the coins: a gold cross, a small silver vase and "dix plats en argent massif", which Degrand was told had been immediately sold in Plovdiv and melted down by the buyer. Subsequently the consul visited the purchaser of the plates, who confirmed that he had melted down some, but had kept three to be traded as antiquities, and these were later acquired by Schlumberger. The consul did not fail to visit the find spot of the hoard, a hill with the ruins 

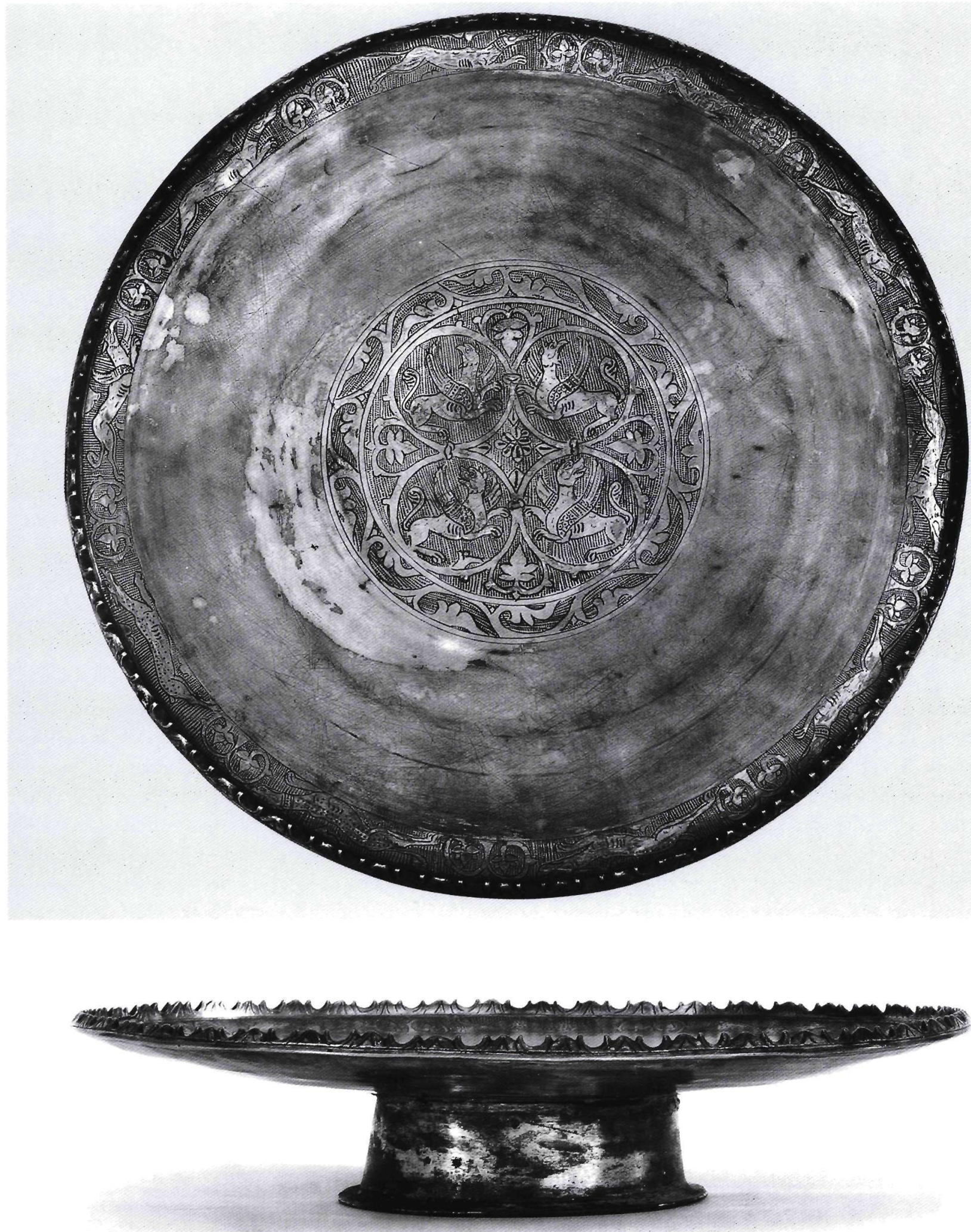

Fig. 20 a-b. Footed plate from the Izgirli Treasure with fantastic animals, 12th century. Paris, Cabinet des Médailles (photo: courtesy of the Cabinet des Médailles). 

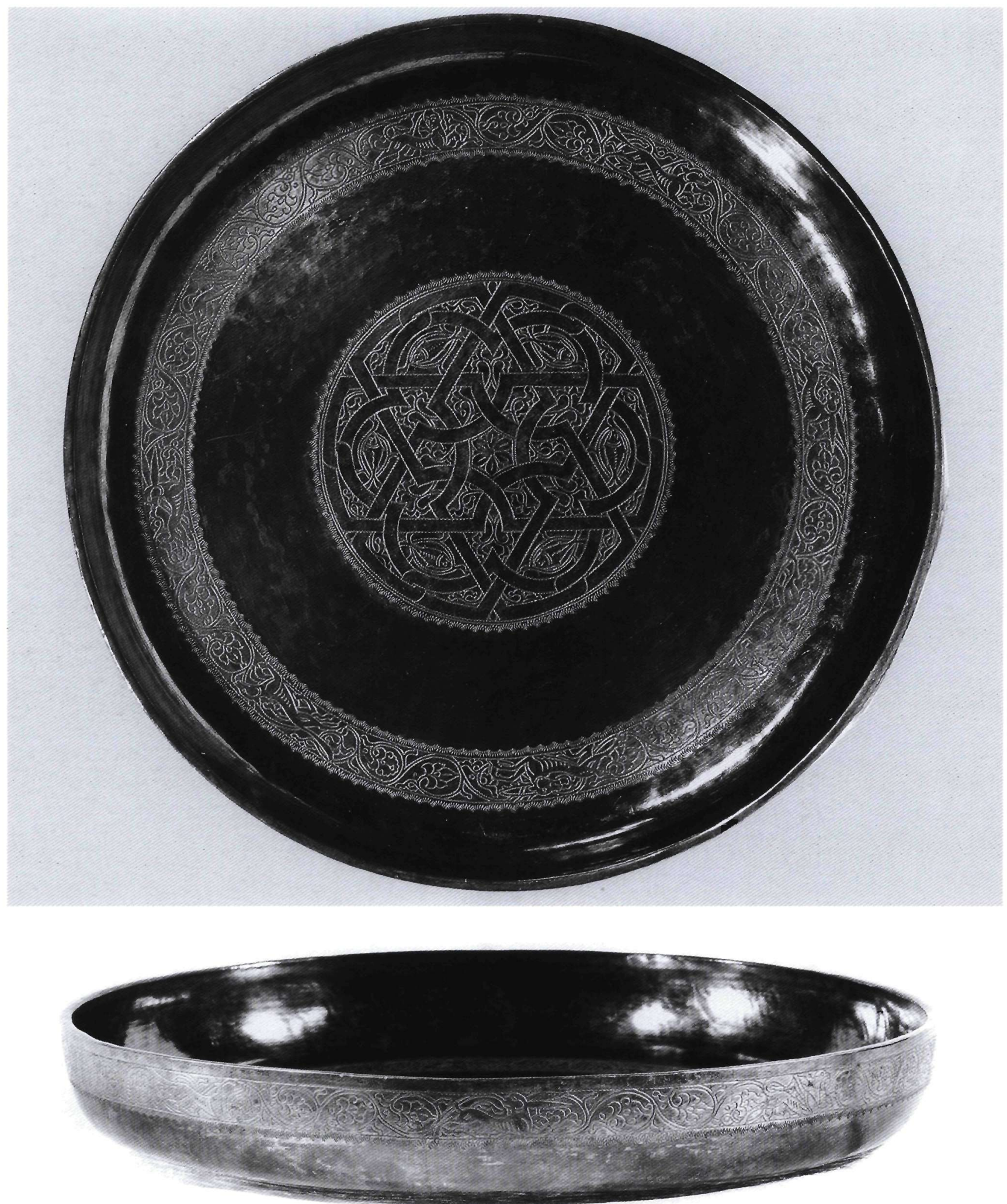

Fig. 21 a-b. Dish from the Izgirli Treasure with a star interlace, 12th century. Paris, Cabinet des Médailles (photo: courtesy of the Cabinet des Médailles). 
of a castle outside Izgirli, where gold coins had previously been discovered by the inhabitants.

The discovery of the coins could only be used as a chronological framework for the dishes if their provenance was a systematic excavation or at least if we had access to the specific coins to verify Degrand's dating. As neither is the case, all we can say is that the evidence of the combined discovery of the Izgirli dishes and coins of the three Komnenoi does not clash with the 12th century background suggested by the iconographic associations. Equally significant is the evidence of the find spot, near Philippopolis, as it coincides with the information concerning the new treasure. It should be noted that at the time in question Philippopolis was a key city of Byzantium, where several major figures of the central imperial stage held important posts, including the metropolitan Michael Italikos who took active role in the negotations with the Crusaders of the second crusade and Niketas Choniates who served as governor of the city, when Frederick Barbarossa passed through. ${ }^{103}$

The thirteenth plate: the identity of the owner

We have thus far been examining the nine dishes of the new treasure and the three pieces of the Izgirli treasure as a potential single group, taking into consideration their common characteristics and the information as to their common provenance. The problem of identifying these twelve dishes takes on a new turn with the evidence of one further dish, which today belongs to the same private collection as the nine presented above but is not being offered for sale (fig. 22). According to the owner, the dish was bought by his father together with the others and comes from the same find. It is preserved in an excellent state, and its shape is similar to dishes nos 3 to 9 , though the diameter is smaller $(24 \mathrm{~cm}$.). The dish bears in its centre as sole decoration a circular inscription framed by pairs of engraved lines. The inscription is written in literary Greek, in capital letters, and reads:

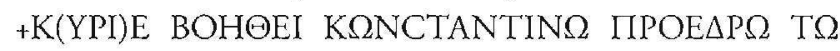
A^ANQ (Lord help Constantine Alanos, Proedros).

Palaeographic evidence tells us that the form of the letters $^{104}$-e.g. the $\mathrm{K}$ with the curved ends, the $\Omega$ with the closed, curving extremities and the closed shape of the $C$ and the $\mathrm{E}$ - occur in late 11th and, especially, 12th century inscriptions on works of art ${ }^{105}$ and wall paintings. ${ }^{106}$ Similar forms of lettering occur in manuscripts with 'epigraphische Auszeichnungsmajuskel' script, which also date from the same period. ${ }^{107}$

The person mentioned in the inscription was probably the owner of the whole group of plates. The office of Proedros was one of the highest-ranking in the 10th century, but by the 1lth it had become less exclusive. From the middle of that century the title was regularly conferred on members of the military aristocracy, but no references can be found after the mid-12th century. ${ }^{108}$ The office was also an ecclesiastical one which is frequently mentioned on lead seals throughout the 13th century, ${ }^{109}$ but the inscription on the plate does not suggest that Alanos was an ecclesiastic, as it lacks the conventional reference to the diocese where he was serving. Prof. Werner Seibr has studied the lead seals referring to Alanoi and has generously made available to us his unpublished data on the subject: ${ }^{10}$ A certain Constantine Alanos, without the addition of any title, occurs on a lead seal now at Dumbarton Oaks (DO 58.106.2314), which has been dated to the second half of the 11th century. A Proedros Alanos, whose baptismal name is unknown, is found on another lead seal dating from the same period (DO 58.106.31930). The name is also mentioned by Skylitzes in connection with campaigns of the year 1045 , during which a military official called Constantine Alanos held the title of Magister."

References to the name Alanos in surviving lead seals do not exist from the 12th century. However Alanos is not necessarily a family name but may rather refer to the nationality of the owner, and in spite of the lack of seals citing the name, the presence of Alans (Georgians) on Byzantine territory is attested until the 13th century, mainly as mercenaries. ${ }^{12}$ Indeed we know of references to Georgians in the Philippopolis area, where the dishes are reported to have been discovered. The first and better-known involves the Petritzos monastery (Bachkovo) which was founded by Gregory Pakourianos in $1083 .^{1.33}$ Not only was this monastery a place of pilgrimage for Georgian monks but, according to the typikon of the founder, the members of the community were required to be exclusively Georgian and the monastery remained under Georgian control until the 14th century. ${ }^{114} \mathrm{~A}$ second, particularly interesting piece of evidence is provided by Choniates, who describes how during Barbarossa's siege of Philippopolis in the Third Crusade (1189) a battle took place at the castle of Prousenos outside the city, 


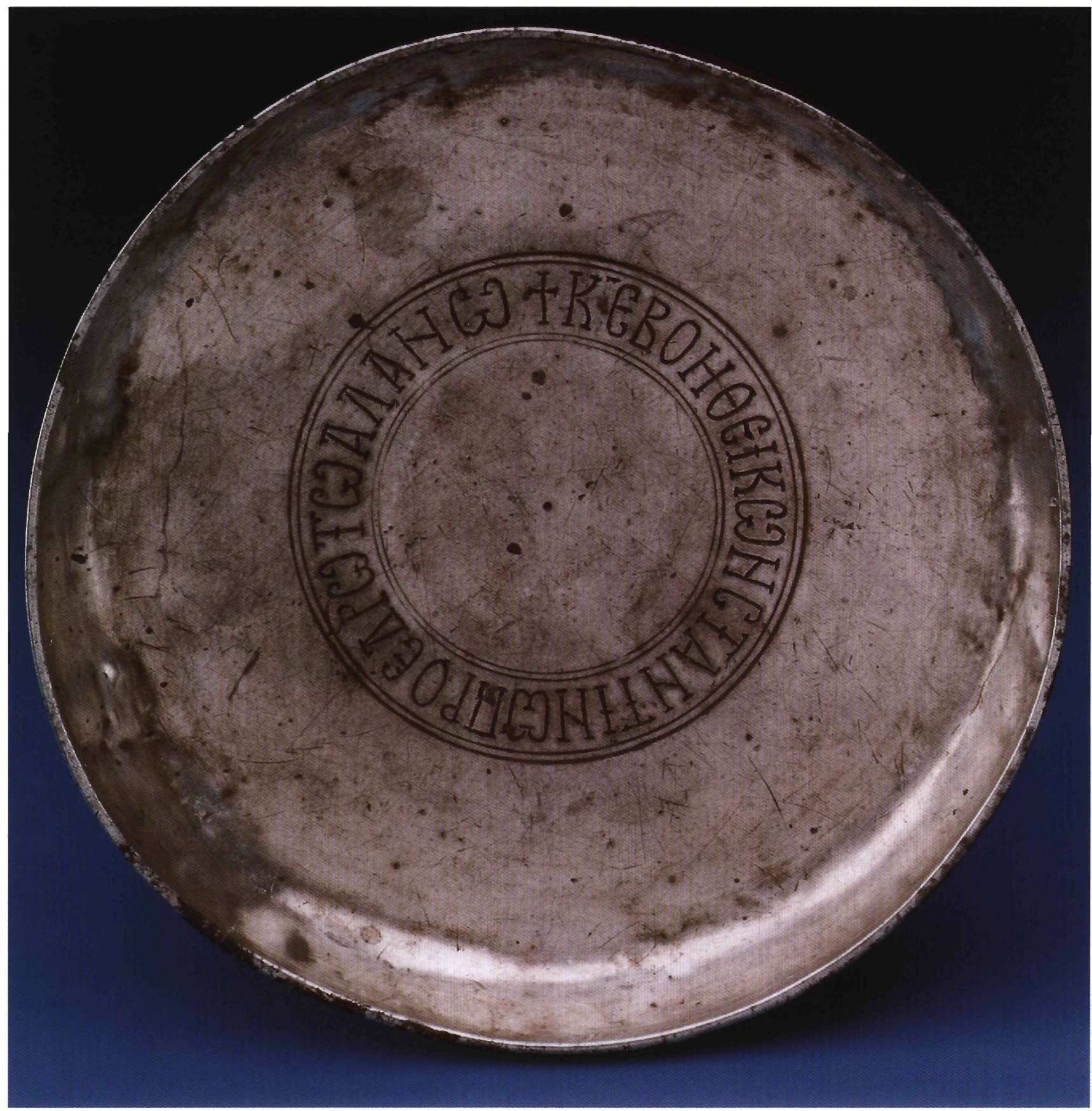

Fig. 22. Dish inscribed with the name of Constantine Alanos. Private collection.

in which the Alans put up a heroic struggle under the leadership of Theodore Vranas. ${ }^{15}$

The treasure and its historical context

The information and comparative material contained in this article indicate very clearly not only the many as- sociations between the dishes and Byzantine and Islamic works, but also the parallels with certain 12 th-century items from the Crusader East. The adoption and appropriation of Islamic motifs in Byzantine art is a wellknown phenomenon which is mentioned in Byzantine sources and can be observed in specific works of art. An 
earlier phase in the relationship between Byzantium and Islam might be characterised in terms of the diplomatic missions between the court and the exchange of rare and precious gifts described in the sources. ${ }^{116}$ In the words of Oleg Grabar, this is a "shared culture of objects" involving rulers and highly placed court officials. ${ }^{17}$ The celebrated story of Constantine Porphyrogennetos gazing in admiration on an Arab bowl in the privacy of his apartments is sufficient to indicate the beginnings of the social acceptability of Islamic art. ${ }^{118}$ By the 12th century, however, the world of the Eastern Mediterranean had expanded, resulting in a proliferation of political centres and the development of the market economy, and Byzantium was now part of the wider framework of commercial intercourse between Italian maritime cities, the Crusaders and the Muslims. ${ }^{119}$ The direct consequence was the development of provincial urban centres, the increased level of exchange and the widespread distribution of products which were no longer restricted to the exotica destined for the emperor's Cabinet of Curiosities. ${ }^{120}$ By now the links with Islamic art do not reflect court taste alone, and the "shared culture of objects" involves not only the imperial milieu but also the humble Corinthian potter. Islamic motifs become part of the general vocabulary of Byzantine art used by the rising local aristocracy and the middle classes, both in parallel with and as alternatives to explicitly Christian and Byzantine themes.

By this time the relationship between Byzantium and the Islamic world is not defined in terms of diplomatic missions and border incidents, but by continuous contact and co-existence within Asia Minor. The movement of an active dynamic from Byzantium to the Sultanate of Rum and back again is illustrated by the flow of claimants to the throne and of disaffected high officials, who became converts either to Islam or to Christianity according to circumstances. At a different social level large numbers of Turkish mercenaries were enticed into joining ranks of the Byzantine army, and many of these ended up settling on Byzantine soil. ${ }^{121}$

Yet relations berween Byzantium and Islam are only one aspect of the mosaic of the 12th-century Eastern Mediterranean. The catalytic role was undoubtedly played by the bold thrust of Christians from the West -the Italian maritime commercial states and the Crusader champions of the faith. Western mercantile communities had a strong presence in Constantinople ${ }^{122}$ but it may also be signifi- cant that during their progress through the territories of the Byzantine empire the Crusaders exchanged silver vessels in their transactions with the local money-changers. ${ }^{123}$ Unfortunately we do not know what type of silverware this was -whether it was brought from their country of origin or appropriated en route as part of the spoils of war from the regions through which they had passed. ${ }^{124}$

In Byzantium this osmosis of multifarious cultural elements had its origin in, and was reinforced by, the official political ideology of the Komnenoi in the 12th century, best illustrated by the brilliant career of Manuel I (11431180). ${ }^{125}$ Tournaments organised by the emperor according to the practices of Western chivalry, the erection of Islamic buildings in Constantinople and state visits by Seljuk and Western rulers were all notable events which bore witness to the new spirit. ${ }^{126}$ This ideology and the secular activities of the imperial court are reflected in contemporary historical and literary texts. It has been plausibly suggested that the account in Vat. Gr. 1409 of a western-style tournament focusing on the figure of the Byzantine emperor may be an ekphrasis, a description of an actual representation of the subject. ${ }^{127}$ The description of the heroes who take part in the tournament could equally well be applied to the hunters on the two dishes: dressed in a short thigh-length chiton, and with their himatia swirling behind them, they brandish their spears and shields. Conversely, the depiction of the exploits of the Seljuk Sultan on the walls of the residence of Alexios Axouch -instead of those of the Byzantine emperor- might later have been used to support accusations of treason against its owner, but at the time of its execution it would have been viewed as acceptable, if unprecedented, by the imperial circles in which Axouch moved. ${ }^{128}$ As regards the depiction of the Sea, a literary parallel can be found in the celebrated romance of Hysmine and Hysminias, where Hysmine gives an eloquent description of her escape from a shipwreck by riding naked on a sea monster. ${ }^{129}$

The literary work which epitomises the contemporary heroic, aristocratic spirit is unquestionably the poem of Digenes Akritas. ${ }^{130}$ The hero who, as his name indicates, was himself the offspring of two races -with his prowess on the battlefield and in the chase and the luxurious magnificence and the romantic eroticism which governed his daily life-could be directly associated with the ideal portrait of the 12th-century Byzantine emperor. ${ }^{131}$ At the same time the descriptions of banqueting and 
hunting scenes, of heroic exploits and romantic episodes between Digenes and his wife Eudokia are the literary parallels to the iconography on the silver cups from Beriozovo, Nenetz, Vilgort, Chernigov and the former Vasilevsky collection. ${ }^{132}$

The dishes discussed here are primarily products of the common aesthetic and the mixed iconographic vocabulary which developed in the Eastern Mediterranean in the 12th century. Their notable thematic variety and multifarious ornamentation, when combined with

\section{Aprendix: Catalogue}

1. Footed plate: diam. $29 \mathrm{~cm}$. h. $5.5 \mathrm{~cm}$. h. of foot 3.2 $\mathrm{cm}$. weight $846.9 \mathrm{gr}$. Condition good. All the decorative features display traces of the original gilding. The underside of the foot has an incision in one place, which has not resulted in damage to the metal.

The plate has the shape of a flat bowl with an integral raised rim decorated with alternating crescents and halflogenzes. The central medallion shows a hunting scene with a horseman armed with a kite-shaped shield and a spear; below the horse's feet a hunting dog pursues a hare whose head is turned backwards. The figures are flanked by stylised bushes and trees. The medallion is encircled by a band of undulating stalks with trefoil offshoots. The representations have a dot-punched background.

The edge of the interior is surrounded by a decorative band of six pairs of running animals interspersed with vegetal scrolls enclosing two palmettes. The animals on the band are, in order: lioness and antelope; dog and hare looking backwards; dog and fox with bushy tail looking backwards; lioness and antlered deer; dog and hare clutching a leaf in its mouth; griffin and horse. Above and below the animals are highly stylised palmette sections and droplet motifs.

The cylindrical foot was formed separately by hammering and then attached to the underside of the bowl. At the centre of the underside the turning point where it was attached to the lathe is visible.

2. Footed plate: diam. $26.5 \mathrm{~cm}$. h. $5.4 \mathrm{~cm}$. h. of foot 3 $\mathrm{cm}$. weight $757.4 \mathrm{gr}$. Condition good. The gilding is badly damaged, and is barely visible on the central medal- the epigraphic evidence of the last dish and the information provided by the Izgirli hoard, point strongly to a provenance in the environment of 12 th-century Byzantium. The inconsistencies noted in the quality of the execution of the dishes suggest that they were probably produced by different craftsmen or workshops. In any case we have no reason to believe that the modern concept of the uniform "set" or "dinner service" had any place in the aesthetics or the practices of the Byzantine era. ${ }^{133}$

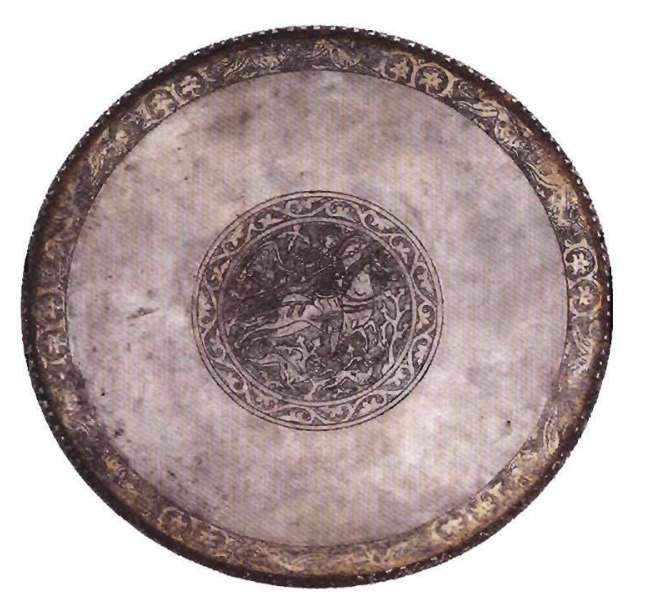

1.

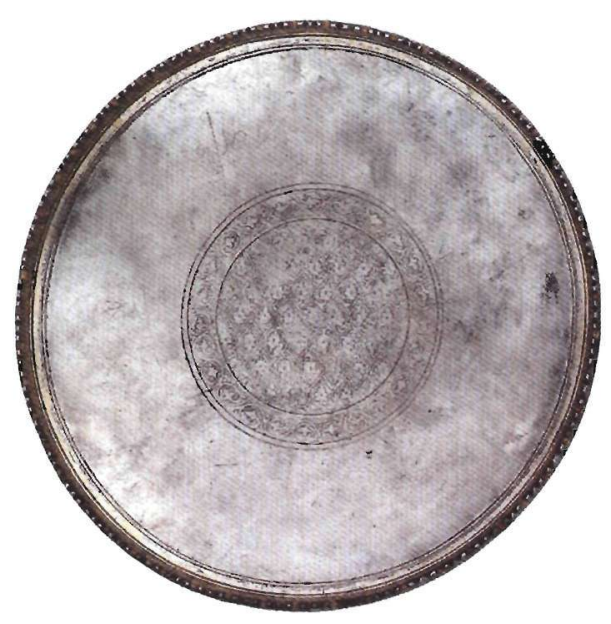

2. 
lion. Letters of the Greek alphabet are crudely scratched mainly on the underside of the plate. Cruciform marks on the main surface.

The central medallion is decorated with a vegetal ogival network forming heart shapes on the upper and lower sides and containing pointed multi-lobed leaves facing in two directions. The medallion is surrounded by a band of undulating stalks with rounded offshoots enclosing trefoil leaves. The background is dot-punched. The engraving generally has a rather flat appearance, which may result from the original execution or from extensive usage. The edge of the interior is encircled by simple engraved lines. The integral ornamental raised rim and the foot resemble those of plate no. 1; here too the turning point of the lathe is visible on the underside.

3. Dish with flat base and low rising sides: diam. 25.8 cm. h. $4.3 \mathrm{~cm}$. weight $613 \mathrm{gr}$. Condition excellent. The gilding is not visible to the naked eye.

The decoration of the central medallion is a condensed version of the hunting scene on plate no. 1 , without the dog and the hare. There are small discrepancies in the position of the spear and of the heads of the rider and the horse.

4. Dish with flat base and low rising sides: diam. 32.6 cm. h. $5 \mathrm{~cm} .964 .4 \mathrm{gr}$.

The largest of the nine plates. The sides have cracked in places and been repaired. The central medallion contains a depiction of the Sea personified as a partly nude woman, riding on a sea monster with an oar and a boat in her hands. She is flanked by four fish. The medallion is surrounded by a three-ply chain band, and the background is ring-punched. The interior of the dish is edged with a continuous band of heart shapes enclosing trefoil palmettes. On the exterior, just below the rim, is a narrow band with undulating stalks and half-palmette offshoots. All the ornamentation is gilded.

5. Dish with flat base and low rising sides: diam. 29.2 $\mathrm{cm}$. h. $4.6 \mathrm{~cm}$. weight $1043.1 \mathrm{gr}$.

Later engraving can be found on both sides of the dish, including an undecipherable cursive inscription. The central medallion is decorated with four undulating stalks which sprout from a circle decorated with four 'winged' split leaf palmettes. Spiky acanthus leaves and small spiral shoots grow from the stalks, and at points where the stalks divide they are encircled by a thin ribbon.

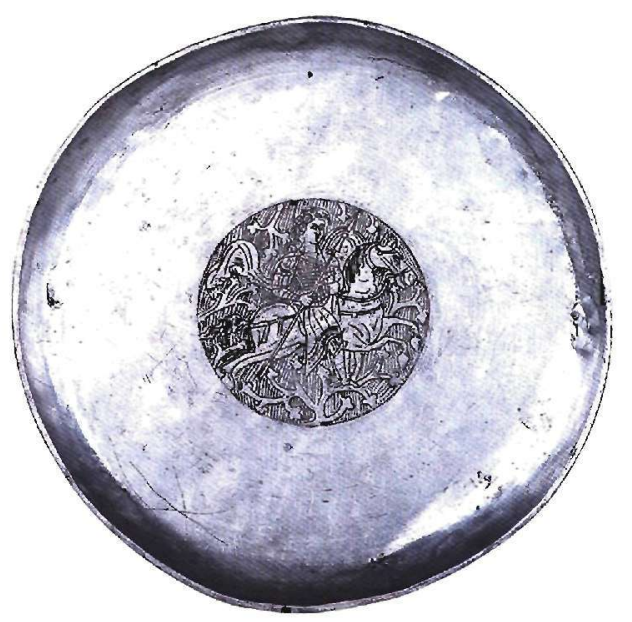

3.

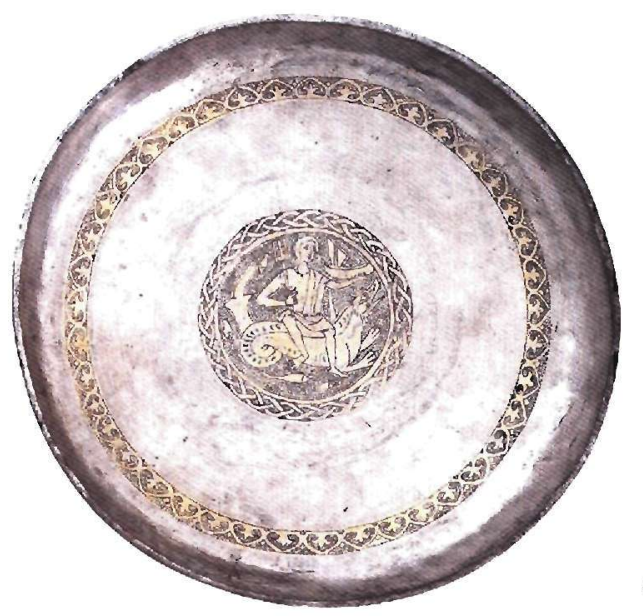

4.

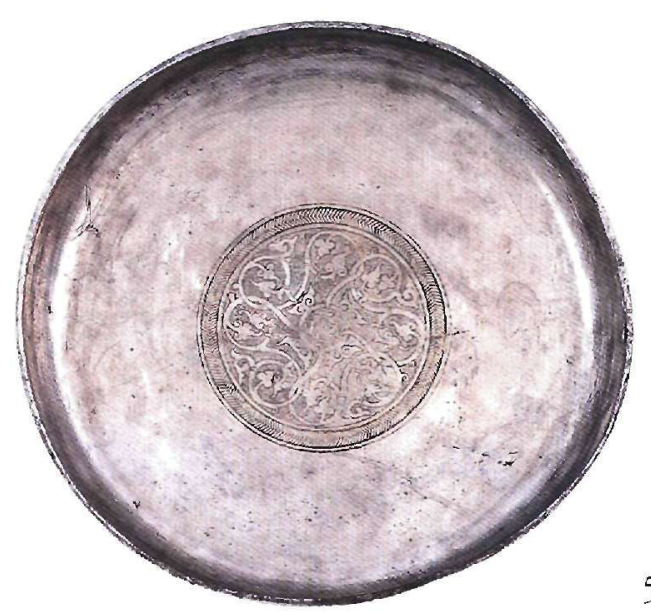

5. 


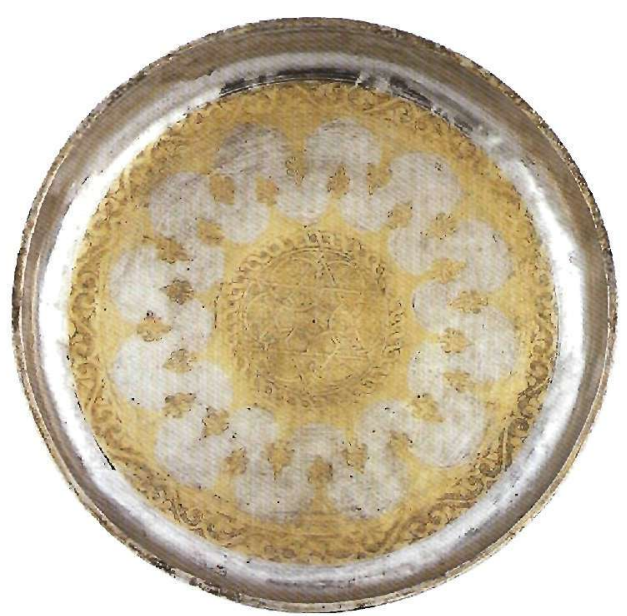

6.

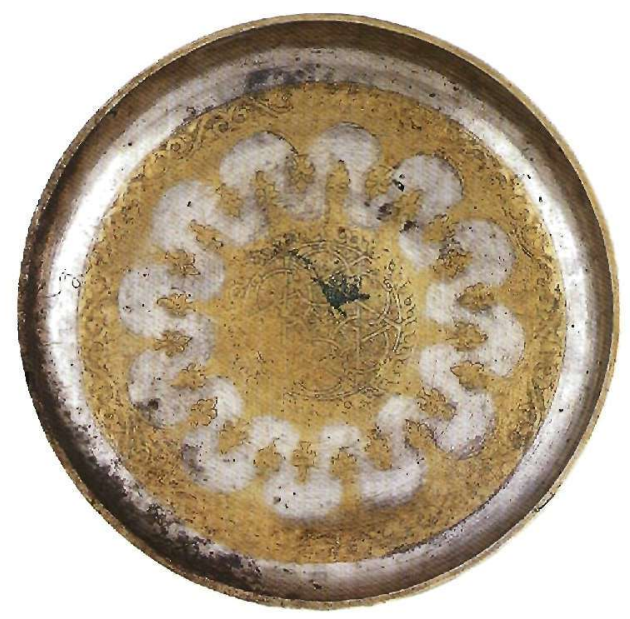

7.

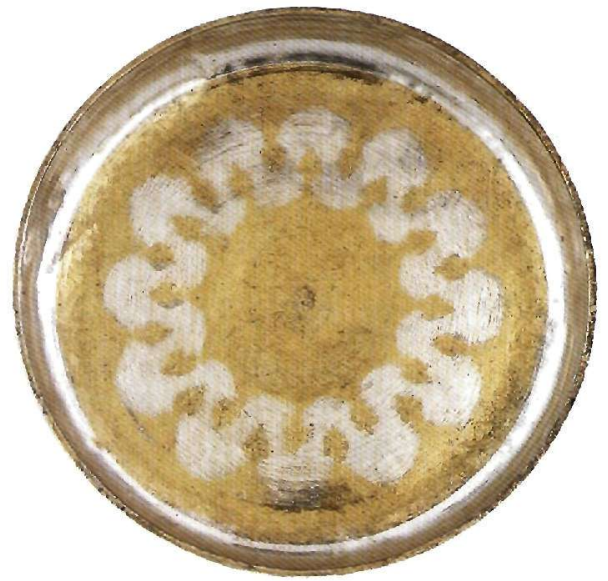

8.

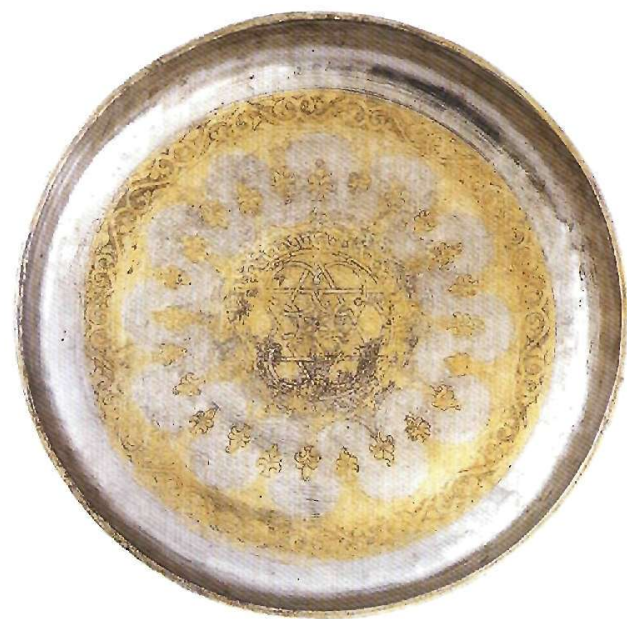

9.

ed star formed from two interconnected triangles and with six semi-circles. The sides of the triangles have in their centre a characteristic indentation which produces rhomboid and parallelogram motifs emanating from and interwoven with the triangles. The medallion is edged with guilloche, which is in its turn edged by a series of twelve inverted semi-circular arcs, with five-lobed palmettes at their junction points. The background is dot-punched. The plate is encircled by a band of S-shaped undulating stalks terminating in two halfpalmettes. This band is edged with semi-circular arcs terminating in five-lobed palmettes, which in the undecorated area of the plate alternate with the palmettes on the arcs surrounding the central medallion. On the exterior of the rim there is similar decoration with arcs terminating in trilobed palmettes. The gilding on all the motifs is well preserved; the most notable feature 
is the manner in which the gilding 'overflows' the engraved contours.

7. Dish with flat base and low rising sides: diam. 27.5 cm. h. $4.7 \mathrm{~cm}$. weight $566.7 \mathrm{gr}$.

Intense green oxidisation in the centre of the plate. This is the least heavy of the nine plates and in order to give it the same dimensions as the other vessels the craftsman made the walls exceptionally thin, with the result that the engraving appears in relief on underside of the base.

The ornamentation is similar to the preceding dish, but here the central leaf of the palmettes which sprout from the medallion is rounded.

8. Dish with flat base and low rising sides: diam. 28.1 cm. h. $4.7 \mathrm{~cm}$. weight 712.2 gr.

\section{ABBREviations}

Darkevich 1975: V. Darkevich, Svetskoe iskusstvo Vizantinii. Proizvedeniiavizantiniisk khudozhremesla v. Vost. Evrope X-XIIIv. (Moscow 1975).

Bank 1978: A. Bank, Prikladnoe iskusstvo Vizantii IX-XIIvv. Materialy I issledovanniia: Ocherki (Moscow 1978).

Iskusstvo Vizantii 1977: A. Bank (ed.), Iskusstvo Vizantii v Sobraniiakh CCCP (exhibition catalogue, II, Moscow 1977).

\section{NOTES}

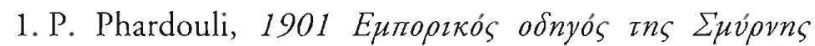

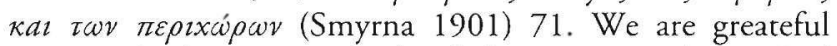
to Matoula Couroupou for her help in tracing the original owner of the dishes. We are also indebted to Vicky Foskolou and Titos Papamastorakis for their fruitful advice during the preparation of the paper.

2. C. Snow, T. Drayman-Weisser, A Technical Study of the Hama Treasure at the Walters Art Gallery, in: M. Mundell-Mango, Silver from Early Byzantium The Kaper Koraon and Related Treasures (Baltimore 1986) 38-65; R. Newman, The Technical Examination and Conservation of Objects in the Sion Treasure, in: S. Boyd, M. Mundell-Mango (eds), Ecclesiastical Silver Plate in Sixth-Century Byzantium (Washington 1992) esp. 77-82; on sources of silver in antiquity and the components of alloys, P. T. Craddock, Early Metal Mining and Production (Edinburgh 1995) 211-28.
On the base a jagged mark arising from the removal of metal, as in plate no. 6. Ornamentation as on plate no. 6 .

9. Dish with flat base and low rising sides: diam. 27.2 cm. h. $4.5 \mathrm{~cm}$. weight $588.9 \mathrm{gr}$.

Ornamentation similar to plate 7 .

Anastasia Drandaki

Curator of the Byzantine Collection

e-mail:anastasia@benaki.gr

Anna Ballian

Curator of the Islamic Collection

e-mail:ballian@benaki.gr

Papanikola-Bakirtzi 1999: D. Papanikola-Bakirtzi (ed.),

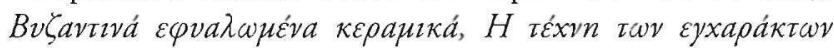
(Athens 1999).

Glory of Byzantium 1997: H. Evans, W. Wixom (eds), The Glory of Byzantium, Art and Culture of the Middle Byzantine Era A.D. 843-1261 (exhibition catalogue, The Metropolitan Museum, New York 1997).

3. Fr. Baratte (ed.), Trésors d'orfeurerie Gallo-romains (Paris 1989) 21-28; Snow, Drayman-Weisser (n. 2).

4. P. O. Harper, P. Meyers, Silver Vessels of the Sasanian Period, Vol. I: Royal Imagery (New York 1981) 150-52, 16063; E. Atil, W. T. Chase, P. Jett, Islamic Metalwork in the Freer Gallery of Art (Washington 1985) 86-87, 188-89.

5. The same has been noted concerning certain objects from the Hama Treasure, suggesting an economy in the use of precious metals, Snow, Drayman-Weisser (n. 2) 43.

6. I. Popović, Les productions officielles et privées des ateliers d'orfevvrerie de Naissus et de Sirmium, in: F. Baratte (ed.), L'argenterie romaine (Antiquité Tardive 5, Paris 1997) 133-44 figs 7-9.

7. Ch. H. Morgan, The Byzantine Pottery, Corinth XI 
(Cambridge-Mass. 1942) 117; J. W. Hayes, Excavations at Saraçhane in Istanbul, 2: The Pottery (New Jersey 1992) 46; Papanikola-Bakirtzi 1999, nos 7, 10, 48, 138-140, 145, 149, $151,153,159$.

8. E. Grube, Cobalt and Lustre, The Nasser D. Khalili Collection of Islamic Art IX (London 1994) 22-23 no. 15; C. K. Wilkinson, Nishapur: Pottery of the Early Islamic Period (New York n.d.) 97 no. 18; 183 no. 4; J. Allan, Review Article of G. Fehervari, Islamic metalwork of the eighth to the fifteenth century in the Keir collection, Oriental Art 12,3 (1976) 302 pl. 8. We are greateful to Sophie Macariou for her prompt response to our request for a photograph of the Fatimid dish.

9. Papanikola-Bakirtzi 1999, nos 12, 29, 33, 142, 158, 161; Morgan 1942, no. 1429 fig. 120, also in Glory of Byzantium $1997,256$.

10. Th. Steppan (ed.), Die Artukiden-Schale im Tiroler Landesmuseum Ferdinandeum Innsbruck. Mittelalterliche Emailkunst zwischen Orient und Occident (Munich 1995) pls $1-2,16$.

11. B. Marshak, M. Kramarovsky (eds), Treasures from the Ob'Basin (exhibition catalogue, St. Petersburg 1996) 26-41; Glory of Byzantium 1997, no. 267 (B. Marshak). We are very grateful to Dr M. Kramarovsky, who has studied the Muzhi finds, for information and assistance. The Muzhi plate, to which we shall return below, has been dated by B. Marshak and M. Kramarovsky to the early 13 th century (1208-1216) and has been attributed to a Greek craftsman working to a Latin commission.

12. A similar observation on the standardisation of dimensions in the production of silver vessels has been made with regard to early Christian silverware, M. Mundell Mango, The Purpose and Places of Byzantine Silver Stamping, in: Boyd, Mundell-Mango (n. 2) 212.

13. A. Drandaki, "YГIEN $\Omega N$ XP $\Omega$ KYPI(E)" An inscribed brass bucket with a hunting scene in the Benaki Museum, Mouseio Benaki 2 (2003) 44-46.

14. E.g. silk textiles: J. Durand et al. (eds), Byzance. L'art byzantin dans les collections publiques françaises (Paris 1992) nos 130, 132; ivories: Glory of Byzantium 1997, no $141(\mathrm{H}$. Maguire); enamels: H. R. Hahnloser (ed.), Il Tesoro di San Marco. La Pala d'Oro (Florence 1965) pl. LVII 148-50; the wall-paintings at the staircase of Saint Sophia in Kiev: V. Lazarev, Old Russian Murals and Mosaics (London 1966) 240 figs 29-31; P. Magdalino, R. Nelson, The Emperor in Byzantine Art of the Twelfth Century, BF 8 (1982) $165 \mathrm{n}$. 110. See also, A. Grabar, L'empereur dans l'art byzantin (London $1971^{3}$ ) 57-62.

15. These eulogies are mainly connected with the emperors Basil I and Manuel I Komnenos, A. Grabar, L'art profane en Russie pré-mongole et le 'dit d' Igor', in: A. Grabar, L'art de la fin de l'antiquité I (Paris 1968) 327; A. Kazhdan, A. Wharton-Epstein, Change in Byzantine Culture in the Eleventh and Twelfth Centuries (Berkley-Los Angeles 1985) 104-
16, 244, Appendix, ex. 17; see also Choniates' description of the representations of the hunts of the emperor Andronicos I Komnenos, C. Mango, The Art of the Byzantine Empire 3121453, Sources and Documents (New Jersey 1972) 235.

16. Iskusstvo Vizantii 1977, no. 666; also in Darkevich

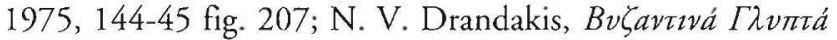
tnऽ Mávns (Athens 2002) fig. 449, where a mounted hunter is depicted on a 12th-century capital; the capitals of this church are decorated with motifs reminiscent of those on the plates of the treasure: rosettes, griffins and other animals within vegetal ornamentation (ibid. 450-55).

17. Grabar (n. 15) III pl. 81; Darkevich 1975 figs 18, 26, 34, 59, 68, 76, 83, 86; Iskusstvo Vizantii 1977, no. 553; Byzantium: An Oecumenical Empire (exhibition catalogue, Byzantine and Christian Museum, Athens 2002) no. 7 (V. Zalesskaya).

18. Apart from the examples of silverware mentioned above, the same motif is found on bronzes, enamels, steatites and ceramics: cf. L. Bouras, Three Byzantine Bronze Candelabra from the Grand Lavra Monastery and Saint Catherine's Monastery in Sinai, DChAE 15 (1989-1990) 23-26 figs 11, 15; Hanhnloser (n. 14) pl. LVII 149; I. Kalavrezou-Maxeiner, Byzantine Icons in Steatite (Vienna 1985) no. 23; Papanikola-Bakirtzi 1999, no. 136.

19. For depictions of military saints in the Middle Byz-

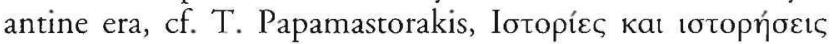

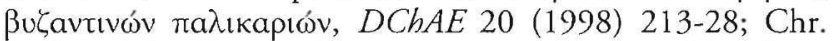
Walter, The Warrior Saints in Byzantine Art and Tradition (Aldershor 2003); Kazhdan, Wharton-Epstein (n. 15) 116.

20. V. Lazarev, Old Russian Murals and Mosaics (London 1966) fig. 84. Representations of mounted military saints are found from the 9 th century in churches in Cappadocia; their presence can be explained by the politico-strategic conditions of the area, Walter (op. cit.) 55-56; id., Saint Theodore and the Dragon, in: Chr. Entwistle (ed.), Through a Glass Brightly, Studies in Byzantine and Medieval Art and Archaeology Presented to David Buckton (Oxford 2003) 99-102.

21. Kalavrezou-Maxeiner (n. 18) nos 6, 8, 11, 15, 21.

22. Grabar (n. 15) III pl. 80 a-b; Darkevich 1975, figs 104-62; no. 552; Bank 1978, 46-51; Y. Piatniski et al. (eds), Sinai, Byzantium, Russia, Orthodox Art from the Sixth to the Twentieth Century (London 2000) no. B82. We are greateful to Doctor R. Yuri Piatnitsky, Curator and Doctor Vladimir Matveev, Dep. Director of The State Hermitage Museum for providing us with photographs of the Beriozovo bowl.

23. Grabar (n. 15) III pl. 79b; Darkevich 1975, 144-49 fig. 106; the St George on the Beriozovo bowl is slightly more stylised by comparison with the hunters on the dishes, though he is admittedly placed in the interior of the cup, where he would hardly be visible.

\section{Drandaki (n. 13) 43-44.}

25. E.g. manuscripts: typical are the rows of running animals in the illustrations to Pseudo-Oppian's Kynegetica 
in the Biblioteca Marciana, V. Lazarev, Storia della pittura bizantina (Turin 1967) figs 143, 145; J. C. Anderson, Cod. Vat. Gr. 463 and an Eleventh-Century Byzantine Painting Center, DOP 32 (1978) 192-96; sculptures: Drandakis (n. 16) figs $127-29,269-70,426$ (11th and 12th century); ivories: A. Goldschmidt, K. Weitzmann, Die byzantinischen Elfenbeinsculpturen des X.XII. Jahrbunderts (Berlin 1930-1934) pl. 39; Iskusstvo Vizantii 1977, no. 605; D. PapanikolaBakirtzi (ed.), Everyday Life in Byzantium (Athens 2002) no. 656; jewellery: Glory of Byzantium 1997, no. 174 (N. Saraga); ceramics: Papanikola-Bakirtzi 1999, nos 56, 208.

26. Darkevich 1975, figs 83-84; Bank 1978, 51-53; Byzantium: An Oecumenical Empire (n. 17) no. 7 (V. Zalesskaya); Sinai, Byzantium, Russia (n. 22) no. B83 (V. Zalesskaya).

27. See above n. 22.

28. Darkevich 1975, fig. 165; Bank 1978, 55-56; Everyday Life in Byzantium (n. 25) no. 222 (V. Zalesskaya); coloured reproduction of the Nenetz cover in the catalogue The Glory of Byzantium 1997, 223, where it is mistakenly idencified as the vessel which was found near Tartu.

29. Bouras (n. 18).

30. LIMCVIII (1997) 1198-99 s.v. Thalassa (H. A. Cahn); H. Maguire, Earth and Ocean, the Terrestrial World in Early Christian Art (Pensylvania 1987) esp. 20-21; M. Piccirillo, The Mosaics of Jordan (Amman 1993) 96, 98 figs 78, 80.

31. Maguire (op. cit.) passim.

32. E. C. Dodd, Byzantine Silver Stamps (Washington 1961) 256-57.

33. E. Kitzinger, I mosaici del periodo normano in Sicilia, I: La Cappella Palatina di Palermo, I mosaici del Presbiterio (Palermo 1992) figs 180, 182.

34. K. Keiko, The Personifications of the Jordan and the Sea: Their function in the Baptism in Byzantine Art, in: $A \varphi z^{-}$

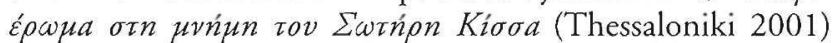
161-212, esp. 183-85.

35. Par. Gr. 139, fol. $419^{v}$, for a good colour reproduction, see A. Cutler, J.-M. Spieser, Byzance médiévale 7001204 (Paris 1996) fig. 115.

36. Cf. Par. Gr. 74, fol. 51v; Lazarev (n. 25) fig. 194.

37. K. Papadopoulos, Die Wandmalereien des XI. Jahrhun-

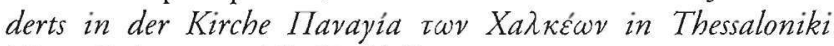
(Graz-Cologne 1966) 63-64 fig. 21.

38. I. Andreescu, Torcello III. La chronologie relative des mosaiques pariétales, DOP 30 (1976) 247-341, esp. 252-54, figs 1,10 . The representation has been restored, but it is the iconography of the original which is of interest here.

39. A. Stylianou, J. Stylianou, The Painted Churches of Cyprus (London 1985) 62-63 fig. 24.

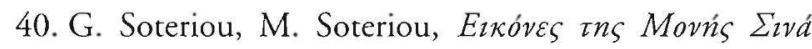
(Athens 1956) I fig. 151; II 130-31.
41. In the restored representation at Torcello the Sea appears to be holding a Cornucopia instead of an oar (Andreescu [n. 38] 253 n. 17). In Kakopetria the object held has been interpreted as a trumpet (Stylianou, Stylianou [n. 39] 62).

42. Note, for example, the resemblance to the sea monster ridden by a nereid on a silver flask in the Hermitage (641651), Everyday Life in Byzantium (n. 25) no. 333 (V. Zalesskaya).

43. Marshak, Kramarovsky (n. 11); a personification of the Sea but with different iconography and style may well be depicted on another silver bowl that was also found in Ob'Basin and has been attributed to Crusader Syria (ibid. no. 70).

44. A. U. Pope, A Survey of Persian Art from the Prehistoric Times to the Present V (Oxford 1938) pl. 584a, see also pl. 586a for a sgraffiato bowl with notched rim. The latest review on Islamic sgraffiato pottery in Grube (n. 8) 115-23.

45. A. Lane, Early Islamic Pottery (London 1947) pl. 24; see also H. Philon, Early Islamic Ceramics (Athens 1980) 190 fig. 384.

46. E. Baer, Metalwork in Medieval Islamic Art (New York 1983) fig. 137.

47. J. Allan, Silver: the Key to Bronze in Early Islamic Iran, Kunst des Oriens 11, 1/2 (1976-1977) 13-21.

48. M. Alison Frantz, Byzantine Illuminated Ornament, ArtBull 16 (1934) pl. XIV,14.

49. Papanikola-Bakirtzi 1999, 57 no. 48.

50. See above n. 28. See also the foliate palmettes on polychrome tiles with representations of saints, Sh. E. J. Gerstel, Ceramic Icons from Medieval Constantinople, in: Sh. E. J. Gerstel, J. A. Lauffenburger (eds), A Lost Art Rediscovered The Architectural Ceramics of Byzantium (Baltimore 2001) 47-48 figs 6-8.

51. K. Weitzmann, G. Galavaris, The Illuminated Greek Manuscripts, The Monastery of Saint Catherine at Mount Sinai (New Jersey 1990) figs 365-66; A. Marava-Chatzinikolaou,

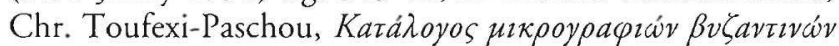

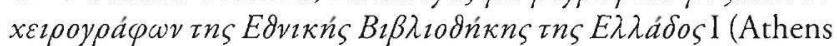
1978) fig. 224; Frantz (n. 48) pls XII,17-22, XVIII,1-3; H. Omont, Miniatures des plus anciens manuscripts grecs de la Bibliothèque Nationale du VIe-XIVe siècle (Paris 1929) pls 98,3, 125; I. Hutter, Corpus der byzantinischen Miniaturenhandschriften (Oxford Bodleian Library I, Stuttgart 1977) no. 38 fol. $2^{v}$ fig. 208; see also R. S. Nelson, Palaeologan illuminated ornament and the arabesque, Wiener Jabrbuch für Kunstgeschichte 41 (1988) 10-12.

52. Lazarev (n. 25) pl. 351; A. M. Romanini et al., L'arte medievale in Italia (repr. Milan 2002) 352. A similar arrangement with heart shapes occurs on a Romanesque bowl from the Dune hoard in which Byzantine influences have been noted, A. Anderson, Medieval Drinking Bowls of Silver Found in Sweden (Stockholm 1983) 23 pl. 17 a-g. 
53. B. Marschak, Silberschätze des Orients (Leipzig 1986) figs $65,77-78,79,81,82-85,93,110-11,115$. See also the ornament on the wall paintings of Panjikent, G. Azarpay, Sogdian Painting The Pictorial Epic in Oriental Art, with contributions by A. M. Belenitskii, B. I. Marshak, M. J. Dresden (BerkeleyLos Angeles-London 1981) fig. 22. On the links between Central Asia/early Islam and Byzantium, Marschak (ibid.) 318-20; P. B. Golden, Khazar Studies (Budapest 1980) 107-11.

54. Wilkinson (n. 8); Terres secrìtes de Samarcande. Ceramiques du VIIIe au XIIIe siècle (exhibition catalogue, Institut du Monde Arabe, Paris - Musée de Normandie, Caen - Musée des Augustins, Toulouse-Paris 1992); J. Raby, Looking for Silver in Clay: A New Perspective on Sāmānid Ceramics, in: M. Vickers (ed.), Pot and Pans, A Colloquium on Precious Metals and Ceramics (Oxford Studies in Islamic Art III, Oxford 1986) 179-203.

55. R. Ettinghausen, O. Grabar, M. Jenkins-Madina, Islamic Art and Architecture 650-1250 (New Haven-London 2001) fig. 189; G. Fehervari, Ceramics of the Islamic World in the Tareq Rajab Museum (London-New York 2000) 56-58 nos 53, 55. See also Wilkinson (n. 8) pl. 5.

56. Raby (n. 54) fig. 27; I. I. Smirnov, Atlas de l'argenterie orientale (St Peterbourg 1909) pl. LXIX,121, 130, 325; see also above n. 53.

57. Papanikola-Bakirtzi 1999, nos 153-55, 207; M. Alison Frantz, Middle Byzantine Pottery in Athens, Hesperia 7 (1938) 450 fig. 11; Morgan (n. 7) fig. 107 pl. XLIV, c, e, f.

58. Y. Tabaa, The Transformation of Islamic Art during the Sunni Revival (London-New York 2001) 77-80.

59. K. A. C. Creswell, Early Muslim Architecture II (Oxford 1940) pls 103-05; K. A. C. Creswell, The Muslim Architecture of Egypt I (Oxford 1952) pls 28a, 83 a-b, 84c, 86c; Raby (n. 54) figs 24, 26. For an indentical star-shaped interlace with indentations in the middle of the sides, see Creswell (ibid.) 366 pl. 117d; also the ornamentation on an 11 th-century Koran with convex instead of concave breaks in the sides, A. Welch, Calligraphy in the Arts of the Muslim World (New York-Austin 1979) 62-63 no. 12.

60. The Arts of Islam (exhibition catalogue, The Art Council of Great Britain, London 1976) 173 no. 185; G. Fehervari, Islamic Metalwork of the Eight to the Fifteenth Century in the Keir Collection (London 1976) nos 66-67 pl. 20 a-b; A. S. Melikian-Chirvani, Islamic Metalwork from the Iranian World 8th-18th Centuries (London 1982) 96-99 nos 26a, 27, and comparative material from Teheran and Ghazni, figs 27 a-c; Baer (n. 46) 129-32, esp. fig. 108; M. Dahncke, Frühislamische Bronzen der Bumiller-Collection (Schriften zur Islamischen Kunst- und Kulturgeschichte 1, Panicale 1988) 30-39; K. von Folsach, Art of the World of Islam in the David Collection (Copenhagen 2001) 308 fig. 485.

61. J. Leroy, Les manuscripts syriaques à peintures conservés dans les bibliothèques de l'Europe et de l'Orient II (Paris 1964) pl. 9,2 .
62. Ch. Oman, Two Siculo-Norman Silver Cups, Burlington Magazine 101 (1959) 350-53; Darkevich 1975, 277 fig. 361.

63. B. Marschak, Zur Toreutik der Kreuzfahrer, in: A. Effenberger (ed.), Metallkunst von der Spätantike bis zum ausgehenden Mittelalter (Berlin 1982) 171; Marschak (n: 53) 112-20. According to Marschak a Western cup found in Kiev, decorated with a geometric interlace, displays a similar fusion of Western and Eastern influences, but the interlace is totally different from that on the dishes of the treasure.

64. M. Vickers, O. Impey, J. Allan, From Silver to Ceramic (Oxford 1986) pl. 65 below.

\section{Glory of Byzantium 1997, no. 176.}

66. J. Allan, The Survival of Precious and Base Metal Objects from the Medieval Islamic World, in: Vickers ( $\mathrm{n}$. 54) 57-70; for a comprehensive overview of Islamic metalwork, see R. Ward, Islamic Metalwork (London 1993).

67. E. Dauterman-Maguire, H. Maguire, Byzantine Pottery in the History of Art, in: D. Papanikola-Bakirtzis, E. Dauterman-Maguire, H. Maguire, Ceramic Art from Byzantine Serres (Urbana-Chicago 1992) 14-16. On the relationship of sgraffiato ware with metalwork, see A. Lane, The Early Sgraffito Ware of the Near East, Transactions of the Oriental Ceramic Society 15 (1937-1938) 41.

68. See above n. 60. Also Melikian-Chirvani (n. 60) 61 figs 21-23, 86-87 no 20; 105-106 no. 36; A. S. MelikianChirvani, Le bronze iranien (Paris 1973) 21. Although we know little about Fatimid metalwork, we may speculate that objects such as the dish at fig. 7 also provided a model for potters.

69. Papanikola-Bakirtzi 1999, nos 29, 30, 31, 143, 144, 198.

70. Ch. H. Morgan (n. 7) 117-23, 127-35, 147-50; the dating of sgraffiato pottery from Corinth has been refined by G. D. R. Sanders, see Papanikola-Bakirtzi 1999, 159-64.

71. Morgan (n. 7) 168-71 attributed the finds to Persia, but fig. 147 is most probably Syrian, Tell Minis group B ware, see V. Porter, O. Watson, 'Tell Minis' Wares, in: J. Allan, C. Roberts (eds), Three Studies in Medieval Ceramics (Oxford 1987) 175-248; also Morgan fig. 149 is probably Raqqa underglaze pottery, fig. 150 is Egyptian lustre, and fig. 148 is probably North African pottery. On the opposite phenomenon of the circulation of Byzantine fine sgraffiato ware in the Eastern Mediterranean, see V. François, Sur la circulation des céramiques Byzantines en Méditerranée orientale et occidentale, in: G. Démians d'Archimbaud (ed.), La céramique médiévale en Méditerranée, Actes du Vle Congrès de l'AIECM 2, Aix-en-Provence 13-18 novembre 1995 (Aixen-Provence 1997) 231-36.

72. The Izgirli dishes have the following dimensions: the two with the ornamental raised rim and the tall foot: diam. $29.5 / 30 \mathrm{~cm}$, h. $5.5 \mathrm{~cm}$, weight $750 \mathrm{gr}$; the third, without foot: diam. $31 \mathrm{~cm}, \mathrm{~h} .4 \mathrm{~cm}$, weight $1250 \mathrm{gr}$ (information as to 
weight comes from the article by $\mathrm{M}$. Degrand, Le trésor d'Izgirli, note de M. Degrand, consul de France à Philippopolis, in: Comptes rendus des séances de l'année 19031 (Paris 1903) 390-96. We are very grateful to Mme. Mathilde Avisseau of the Cabinet des Médailles, who greatly assisted our work on the Izgirli dishes.

73. Other examples of nearly identical Middle Byzantine silver vessels have been discovered on their own, e.g. the two precious bowls from Vilgort and Chernigov, now both in the Hermitage, see Darkevich 1975, figs 1-3, 44-46.

74. Lazarev (n. 25) figs 255-58; Drandakis (n. 16) fig. 426; Papanikola-Bakirtzi 1999, no. 208.

75. C. R. Dodwell, The Pictorial Arts of the West 800-1200 (New Haven-London 1993) figs 205, 273, 329, 346, 370; L.-A. Hunt, The Syriac Buchanan Bible in Cambridge: Book illumination in Syria, Cilicia and Jerusalem of the Later Twelfth Century, in: ead., Byzantium, Eastern Christendom and Islam, Art at the Crossroads of the Medieval Mediterranean II (London 2000) 23-77 figs 37-41; H. Buchthal, Miniature Painting in the Latin Kingdom of Jerusalem (Oxford 1957) pls 13a, $14 a-b, 15 a-b, 16,23 a-b, 47 a-b$.

76. E.g. M. H. Longhurst, Victoria and Albert Museum, Catalogue of Carvings in Ivory, Part I, Up to the Thirteenth Century (London 1927) pls LXVIII-LXIX; E. Kitzinger, Early Medieval Art (London 19873) fig. 39.

77. L.-A. Hunt, Artistic and Cultural Interrelations between the Christian Communities at the Holy Sepulchre in the 12th Century, in: Hunt, Byzantium, Eastern Christendom (n. 75) 281-85 figs 10-12.

78. Apart from the lintel of the Holy Sepulchre, of. the miniatures of the Bury Bible, illuminated by Master Hugo (c. 1135) and the later St Hugh's Bible (1160-1185), Dodwell (n. 75) 341-47, 363-65.

79. J. Allan, Nishapur: Metalwork of the Early Islamic Period (New York 1982) 42-43, 82-85; Ward (n. 66) figs 41-42.

80. See above n. 60. For more eastern Iranian examples with animal friezes, see J. Allan, Islamic Metalwork The Nuhad Es-Said Collection (London 1982) 32-35 no. 1; Melikian-Chirvani (n. 60) 94-96 no. 26, and Baer (n. 46) $175-80$ where it is stated that friezes with running animals against a scroll background become common from the $12 \mathrm{th}$ century onwards.

81. Dahncke (n. 60).

82. E.g. Buchthal (n. 75) pls 42 a-b, $47 a$.

83. E.g. Iskusstvo Vizantii 1977, nos 602, 604; Glory of Byzantium 1997, nos 153-56; Durand et al. (n. 14) nos 15557; Everyday Life in Byzantium (n. 25) nos 221, 627-28, 655.

\section{Mango (n. 15) 234.}

85. E.g. fol. $145^{\mathrm{r}}$ of the 11 th century manuscript no. 146 , of the Historical Museum of Moscow, G. Galavaris, The
Illustrations of the Liturgical Homilies of Gregory Nazianzenus (Princeton 1969) pl. IV,13.

86. Grabar (n. 15) III pl. 54; Galavaris (n. 85) pls IX,5051, LXXXVIII,403-04, 406, XCII,418, 420.

87. A. Bank, Byzantine Art in the Collections of the USSR (Leningrad-Moscow 1966) figs 205-07; Darkevich 1975, 262-65; Iskusstvo Vizantii 1977, no. 551.

88. R. Ettinghausen, The 'Wade Cup' in the Cleveland Museum of Art, its Origin and Decoration, Ars Orientalis 2 (1957) 351-56, see especially the design of the centre of the Vaso Vescovali in fig. T with the arrangement of the fishes in confronting pairs as on the Izgirli dish.

89. On the interpretation of the Kurbinovo Ascension, see L. Hadermann-Misguich, Kurbinovo, Les fresques de SaintGeorges et la peinture byzantine du XIIe siècle (Bruxelles 1975) 171-73; for a good colour reproduction, see Cutler, Spieser (n. 35) pl. 216.

90. On the Muzhi plate, see above n. 11; on the bowl depicting the feats of Manuel, see Mango (n. 15) 228.

91. Degrand (n. 72).

92. G. Migeon, Orfevrerie d'argent de style orientale trouvée en Bulgarie, Syria 3 (1922) 141-44.

93. Grabar (n. 15) I 333, with reference to Russian and Bulgarian publications.

94. Mclikian-Chirvani, Le bronze iranien (n. 68) 12-13.

95. The Arts of Istam (n. 60) 162 no. 160.

96. Raby (n. 54); Dahncke (n. 60).

97. Darkevich 1975, 210-13, 221-29 and passim.

98. Bank 1978, 56-58.

99. Marschak (n. 63) 166-84; also Marschak (n. 53) $112-$ 20. Marschak's view is followed by B. Kühnel, Crusader Art of the 12th Century (Berlin 1994) 117-20.

100. In the catalogue it is mentioned twice, once generally in the context of the attribution of the hoard to the Byzantine periphery, and on another occasion as Islamic comparative material in a reference to the relationship between Islamic and Byzantine art, Durand et al. (n. 14) 339 no. 253 (J. Durand); 392 no. 298 (Chr. Vogt).

101. Degrand (n. 72).

102. On the numerous coins, mainly of the Komnenian era, discovered at Philippopolis and Pazarcik, see the tables published by $\mathrm{C}$. Asdracha, La région des Rhodopes aux XIIIe et XIVe siècles. Etude de géographie historique (Athens 1976) table 2.

103. $O D B 2$ (1991) 1368-69 s.v. Michael Italikos (A.

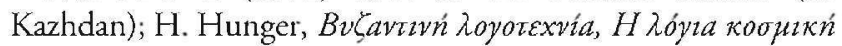

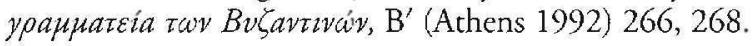

104. We are most grateful to $\mathrm{A}$. Tselikas for his assistance on epigraphical issues. 
105. E.g. on the reliquaries of the Shroud, the holy girdle and the lention in St Mark's sanctuary, Venice and the silvergilt casket with the Four Martyrs from Trebizond, now in St Mark's Treasury, A. Guillou, Recueil des inscriptions grecques médiévales d'Italie (Rome 1996) nos 82, 83, 85, 91; see also the inscriptions on the gilded reliquary cover with the Myrrh-bearers in the Louvre, Durand et al. (n. 14) no. 248 (J. Durand).

106. Cf. the close resemblances in the inscription in the dome of the Cappella Palatina (1143), O. Demus, The Mosaics of Norman Sicily (London 1949) pl. 13.

107. E.g. Weitzmann, Galavaris (n. 51) nos 56, 57; I. Spatharakis, Corpus of Dated Illuminated Greek Manuscripts to the year 1453 (Leiden 1981) figs 244, 256, 273, 316; $\mathrm{H}$. Hunger, Epigraphische Auszeichnung smajuskel, JÖB 26 (1977) 193-210.

108. N. Oikonomides, Les listes de préseance Byzantines du IXe et Xe siècle (Paris 1972) 299; ODB 3 (n. 103) 1727 s.v. Proedros (A. Kazhdan, A. Cutler).

109. $O D B 3$ (n. 103) 1727-28 s.v. Proedros as an Ecclesiastical Title (A. Papadakis).

110. We are also deeply indebted to Dr. Alexandra Wassiliou for her invaluable assistance.

111. I. Thurn (ed.), Ioannis Scylitzae Synopsis Historiarum (Berlin-N. York 1973) 437-38, 438-59.

112. J. W. Birkenmeier, The Development of the Komnenian Army 1081-1180 (Leiden-Boston-Köln 2002) 161-63; Kazhdan, Wharton Epstein (n. 15) 257, Appendix ex. 40. It should be noted that Byzantine sources do not make a clear distinction between Alans, Iberians, Masagetai and Abchasians, see Kazhdan, Wharton Epstein (n. 15) 169.

113. J. Thomas, A. Constantinides-Hero (eds), Byzantine Monastic Foundation Documents, A Complete Translation of the Surviving Founders' Typika and Testaments (Washington 2000) 507-63.

114. Thomas, Constaninides-Hero (n. 113) 508; Moreover, the icon of the Virgin Glykophilousa (late 11 th - early 12th century) was in 1311 given a metal revetment with Georgian inscriptions, an indication of the continuing links between the monastery and the Georgians, M. Panayotidi, H

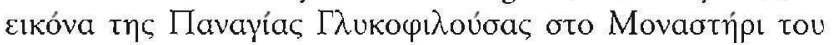

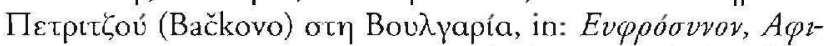

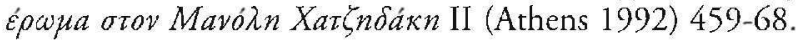

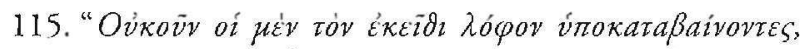

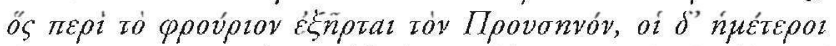

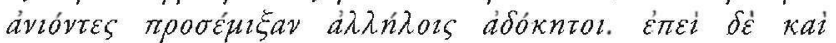

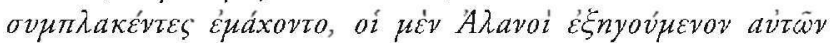

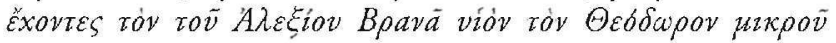

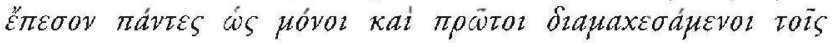
Ahapavoic", I. van Dieten (ed.), Nicetae Choniatae Historia (Berlin-New York 1975) 409, 22-27.

116. Book of Gifts and Rarities (Kitāb al-Hadāya wa alTuhaf), transl. Gh. al-Hijjāwī al-Qaddūm̄̄ (Harvard 1996);
A. Cutler, Les échanges de dons entre Byzance et l'Islam (IXe-XIe siècles), Journal des Savants (1996) 51-66. For a general overview of Byzantine-Islamic relations with previous bibliography, see P. Soucek, Byzantium and the Islamic East, in: Glory of Byzantium 1997, 402-11; A. Ballian, Byzantium and Islam: Relationships and Convergences, in: Byzantium: An Oecumenical Empire (n. 17) 230-38.

117. O. Grabar, The Shared Culture of Objects, in; H. Maguire (ed.), Byzantine Court Culture from 829 to 1204 (Washington 1997) 115-29. A similar approach by A. Cutler, The Parallel Universe of Arab and Byzantine Art (with Special Reference to the Fatimid Art), in: M. Barrucand (ed.), L'Egypte Fatimide son art et son histoire (Paris 1999) 635-48.

118. Cutler (n. 116) 57.

119. P. Magdalino, The Empire of Manuel Komnenos, 1143-1180 (Cambridge 1993) 140-71; A. Kazhdan, Latins and Franks in Byzantium: Perception and Reality from the Eleventh to the Twelfth Century, in: A. Laiou, R. Parviz Mottahedeh (eds), The Crusades from the Perspective of Byzantium and the Muslim World (Washington D. C. 2001) 83-100.

120. G. Dagron, The Urban Economy, Seventh-1'welfth Centuries, in: A. E. Laiou (Editor-in-Chief), Economic History of Byzantium II (Washington D. C. 2002) 401-03; A. E. Laiou, Exchange and Trade, Seventh-Twelfth Centuries, in: Laiou (ibid.) III 736-38.

121. Ch. M. Brand, The Turkish Element in Byzantium, Eleventh-Twelfth Centuries, DOP 43 (1989) 1-25.

122. See above n. 119; also A. Laiou, Byzantine Trade with Christians and Muslims and the Crusades, in: Laiou, Parviz-Mottahedeh (n. 119) 157-61; Ch. Maltezou, II quartiere veneziano di Constantinopoli (scali maritime), @noavptouara 15 (1978) 30-62; P. Magdalino, Constantinople médiévale, Etudes sur l'évolution des structures urbaines (Travaux et Mémoires, monographies 9, Paris 1996) 78-90.

123. Odo of Deuil, De profectione Ludovici VII in orientem, ed. V. G. Berry (New York 1948) 66, 75; Laiou (n. 122) $166,174$.

124. To the best of our knowledge, Crusader silverware displays the mix of Byzantine, Islamic and Western features which is a general characteristic of the period, J. Folda, Crusader Art, in: Glory of Byzantium 1997, 389-91, 398 no. 264; E. Delpont (ed.), L'Orient de Saladin, L'art des Ayyoubides (exhibition catalogue, Institut du Monde Arabe, Paris 2002) 106-07.

125. Magdalino (n. 119) 27-108, where he examines the politics of Manuel's predecessors, Alexios I (1081-1118) and John II (1118-1143), towards the Crusaders and Islam, and passim.

126. Mango (n. 15) 228-29; for the text of Vat. Gr. 1409 which describes the tournament, see Sp. Lampros, 'Ekppaorc

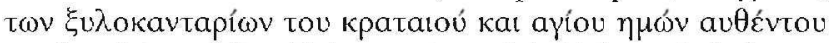

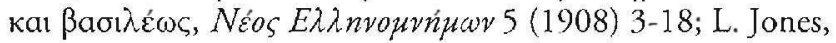
H. Maguire, A description of the joust of Manuel I Komnenos, BMGS 26 (2002) 104-48; Kazhdan, Wharton-Epstein 
(n. 15) 180-85; L.-A. Hunt, Comnenian Aristocratic Palace Decoration: Descriptions and Islamic Connections in: ead., Byzantium, Earstern Christendom (n. 75) I 29-59.

127. See above n. 126.

128. Mango (n. 15) 224-25; Magdalino (n. 119) 218-19.

129. I. Hilberg (ed.), De Hysmines et Hysminiae amoribus libri XI (Vienna 1876) 11.13-14.1; R. Beaton, The Medieval Greek Romance (Cambridge 1989) 77-86; on the dating of the text, P. Magdalino, Eros the King of "Amours": Some Observations on "Hysmine and Hysminias", DOP 46 (1992) 197-204; on the relationship between the text and personifications of the Sea, cf. I. Nilsson, PHANTASIA: A Wise and subtle Artist. Visualizing a Twelfth Century Ekphrasis, in: E. Piltz, P. Åström (eds), KAIROS. Studies in Art History and Literature in Honour of Professor Gunilla Akerström-Hougen (Jonsered 1998) 50-65, esp. 58-59, fig. 10-11.
130. N. Oikonomidès, L'Épopée de Digénis et la frontière orientale de Byzance aux Xe et XIe siècles, TM 7 (1979) 375-97; Beaton (n. 129) 27-48; R. Beaton, D. Risks (eds), Digenes Akrites, New Approaches to Byzantine heroic poetry (London 1993) passim.

131. Grabar (n. 14) 93-97; Kazhdan, Wharton Epstein (n. 15) 117-19; Magdalino (n. 119) 1-2, 420-21, 449.

132. Darkevich 1975, 321-25; Kazhdan, Wharton-Epstein (n. 15) 118 .

133. Nothing of such a kind has ever been noted even in the numerous treasure-hoards of late antiquity, where, on the contrary, silver vessels display a remarkable variety in shape, iconography and technique, cf. Fr. Baratte et al., Trésors d'orfeurerie Gallo-romaine (Paris 1989) passim; H. A. Cahn, A. Kaufmann-Heinimann (eds), Der spätrömische Silberschatz von Kaiseraugst II (Basel 1984) pl. 12.

\section{ANNA MПA $\Lambda \Lambda$ IAN - ANA $\Sigma$ TA $\Sigma I A ~ \triangle P A N \triangle A K H$

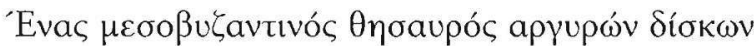

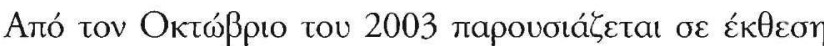

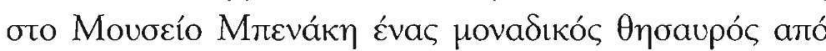

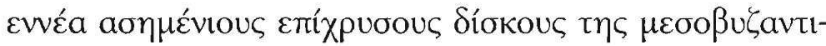

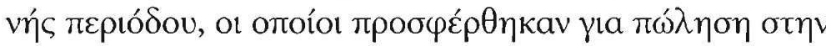

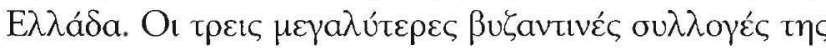

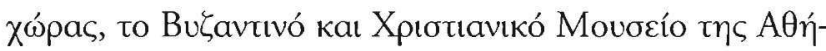

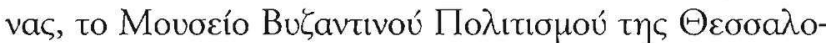

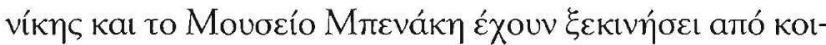

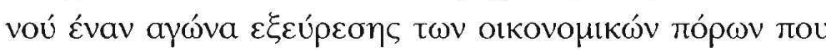

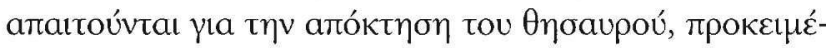

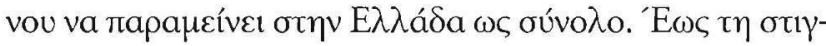

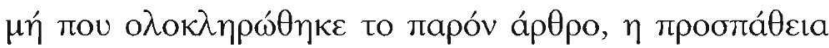

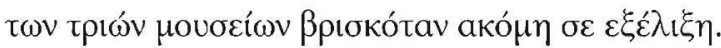

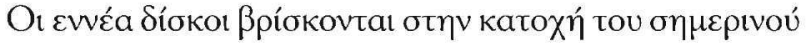

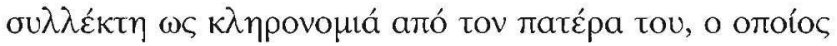

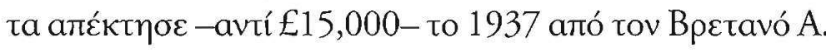

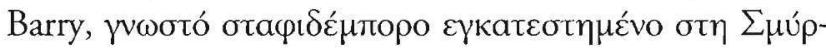

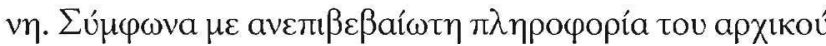

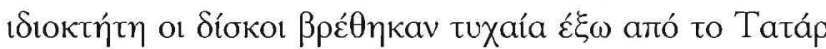

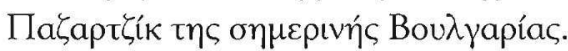

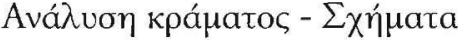

Oı ava

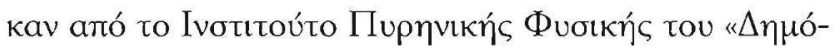

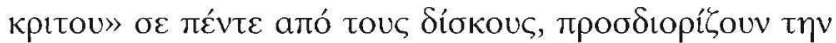

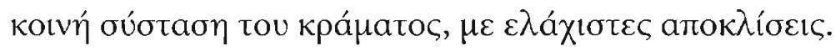

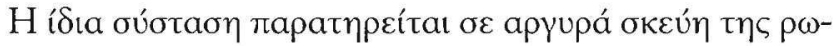

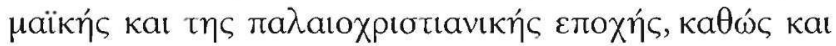

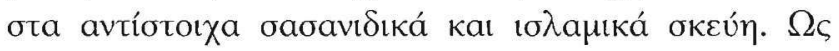

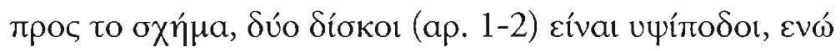

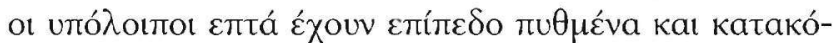

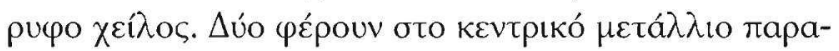

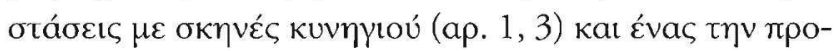

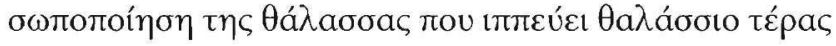

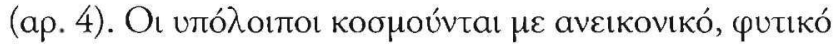

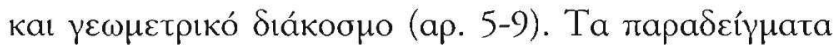

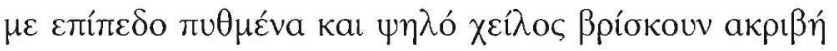

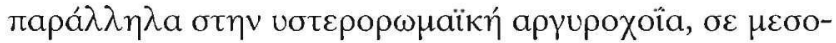

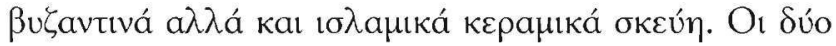

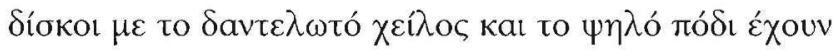

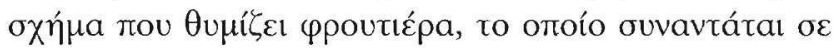

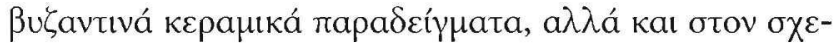

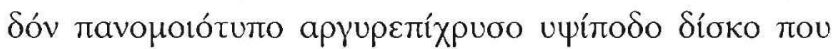

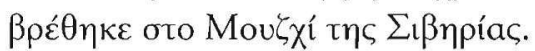

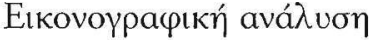

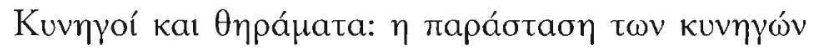

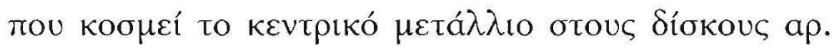




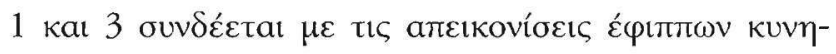

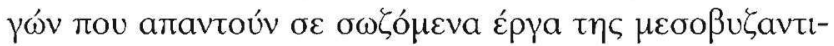

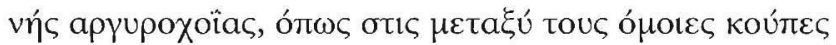

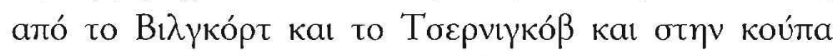

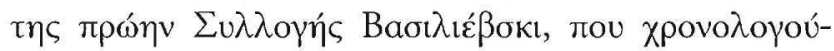
vtat otov 120 at

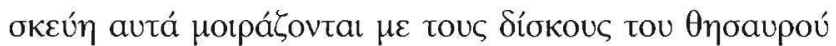

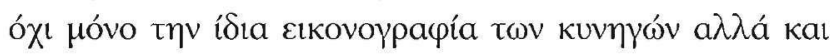

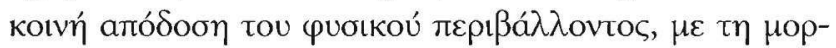

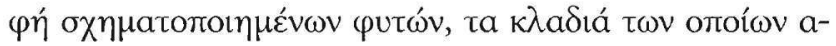

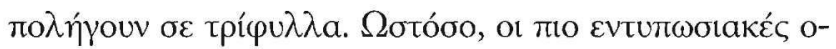

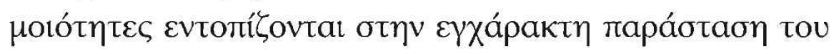

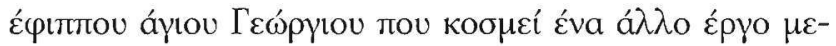

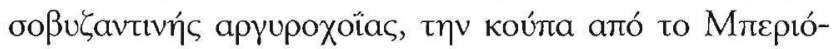
$\zeta o ß o ~(12 o \varsigma$ at.).

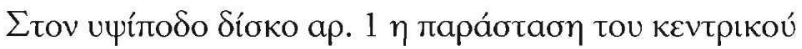
$\mu \varepsilon \tau a \lambda \lambda$ íou $\sigma 0 \mu \pi \lambda \eta \rho \omega ́ v \varepsilon \tau a l$ a

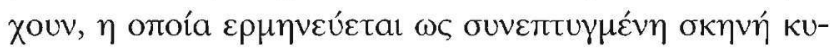

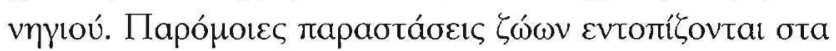

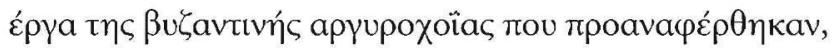

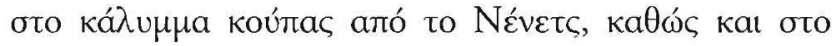

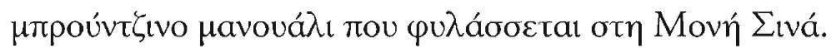

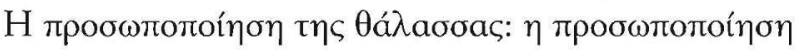

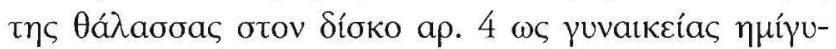

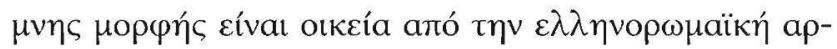

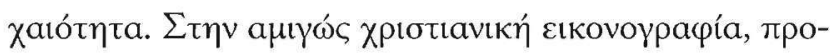

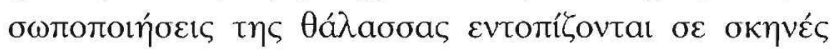

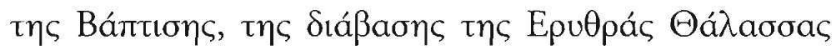

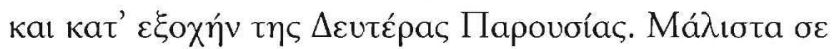

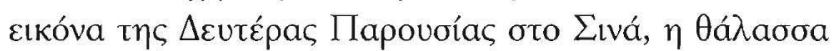

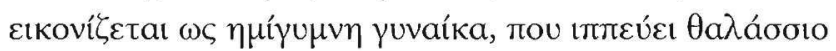

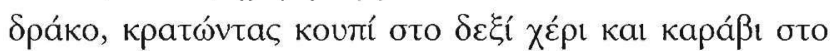

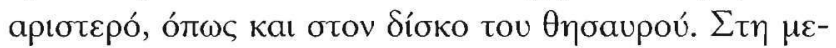

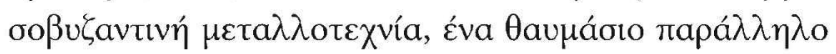

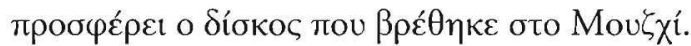

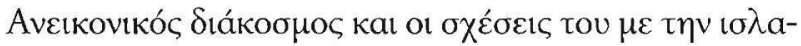

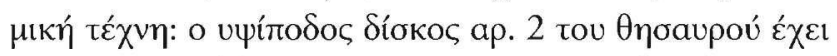

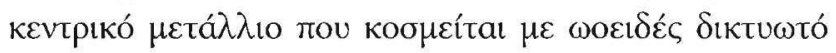

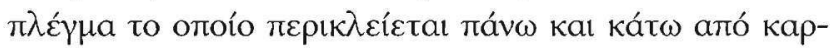

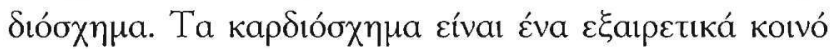

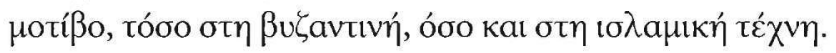

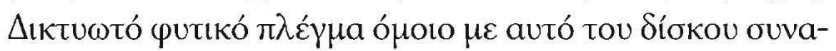

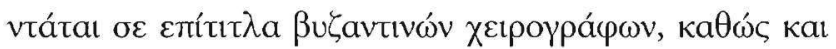

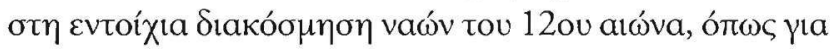

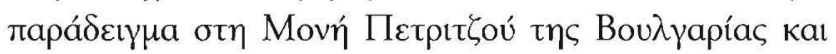

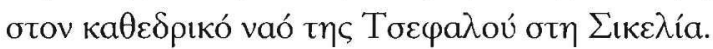

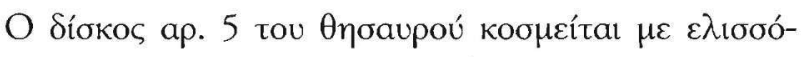

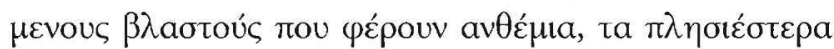

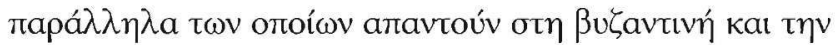

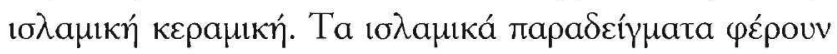

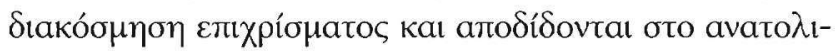

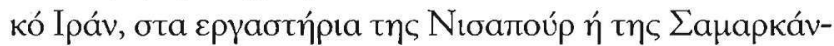

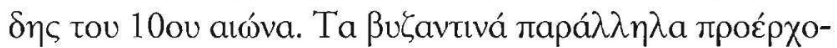

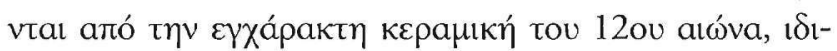

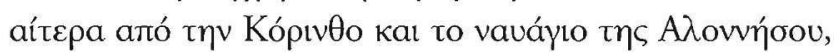

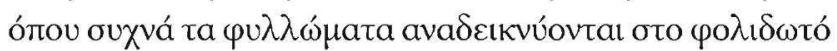

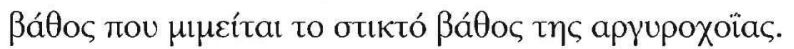

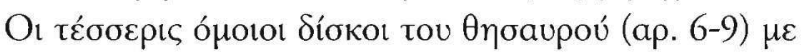

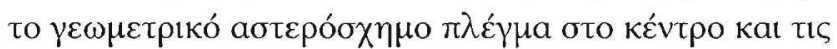

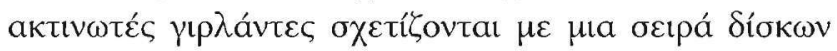

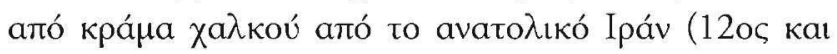

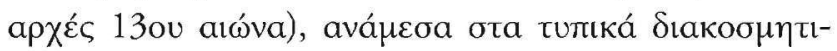

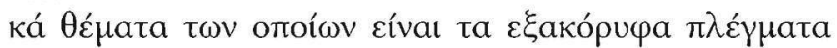

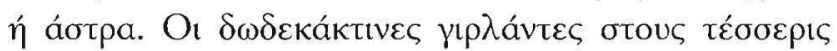

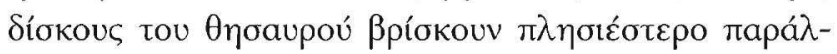

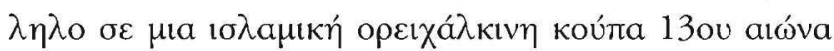

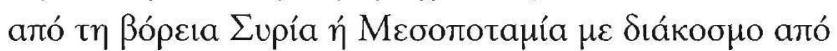

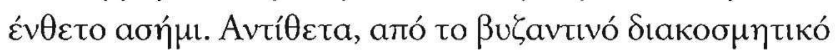

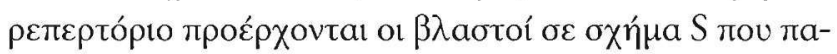

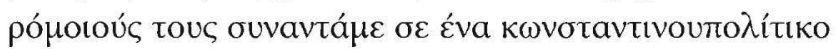

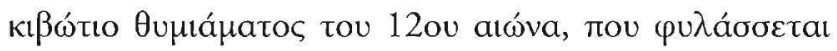

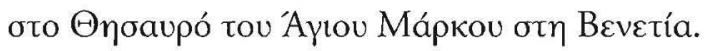

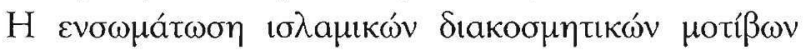

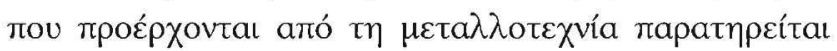

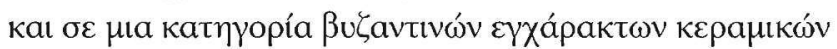

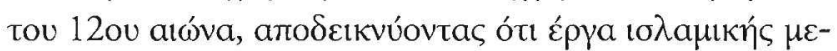

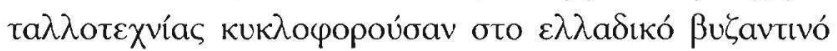

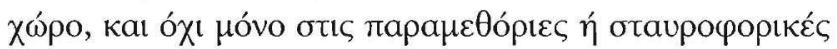

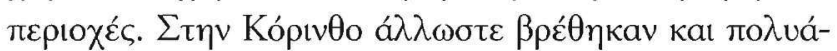

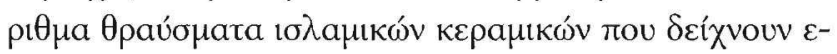

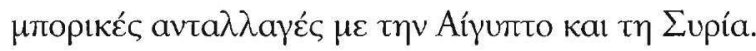

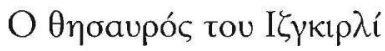

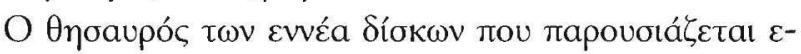

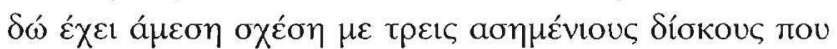

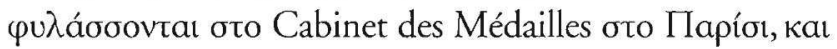

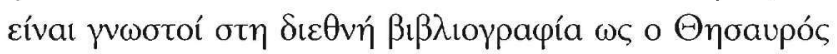

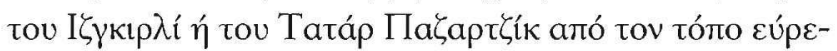

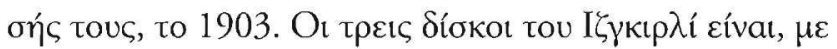

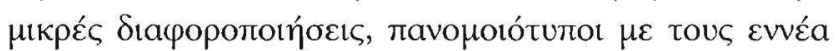

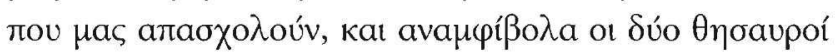

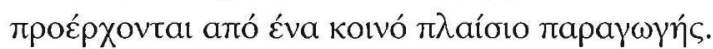




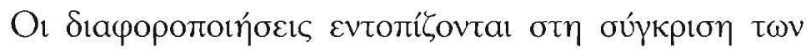

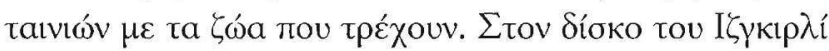

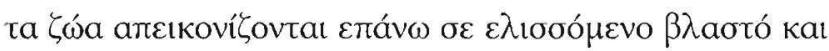

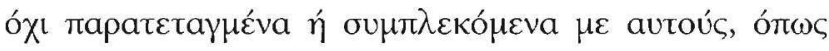

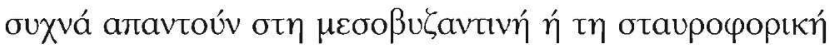

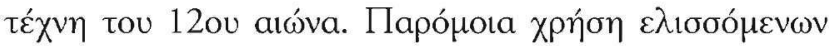

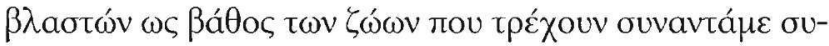

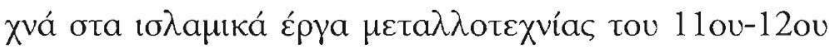

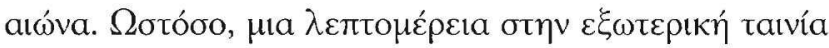

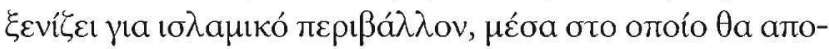

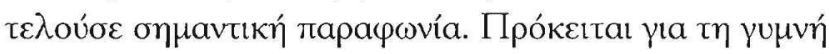

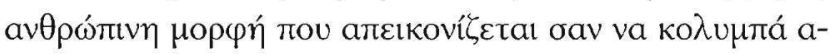

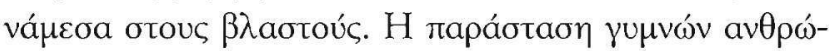

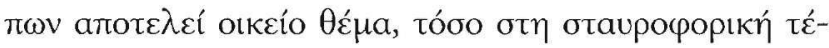

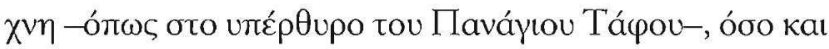

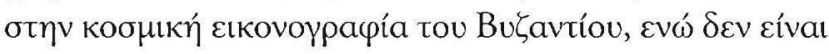

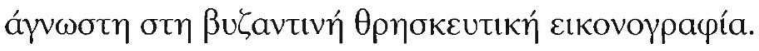

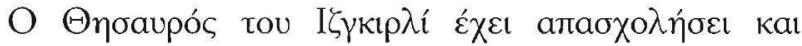

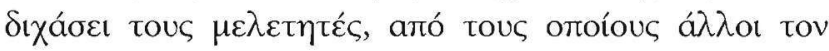

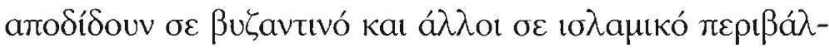

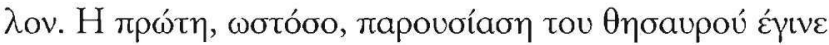

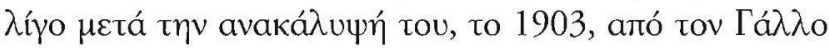

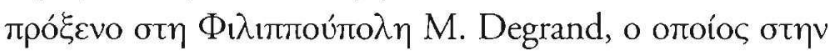

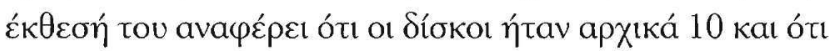

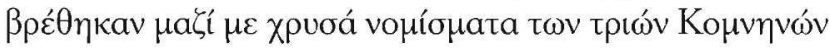

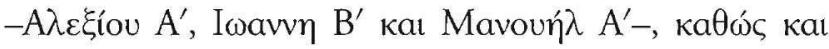

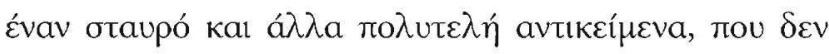

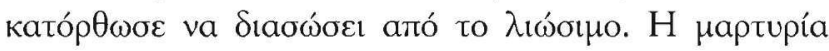

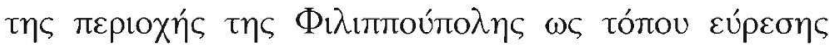

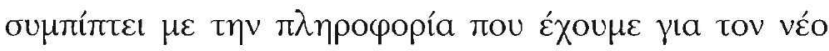

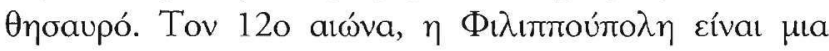

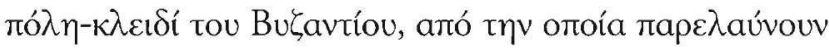

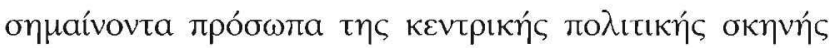
түৎ аuтократорі́as, ó

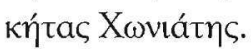

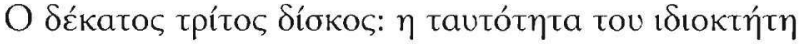

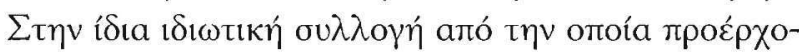

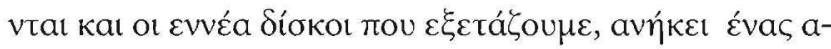

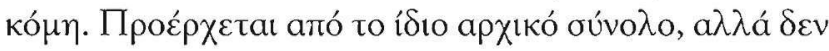

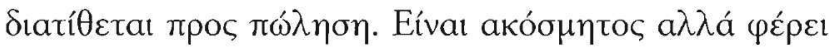

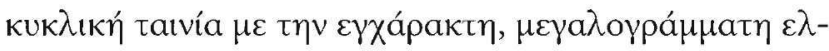

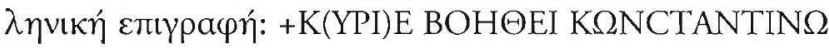
$\Pi P O E \triangle P \Omega T \Omega A \Lambda A N \Omega$.

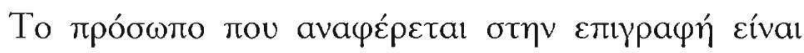

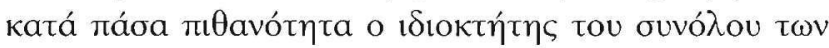

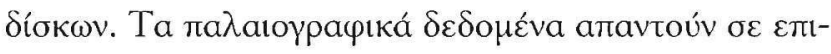

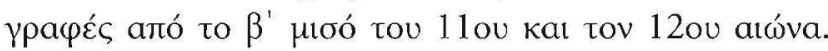

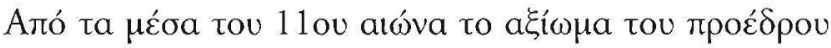

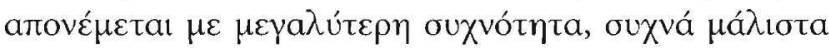

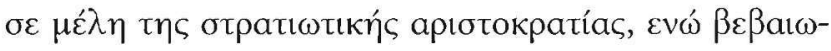

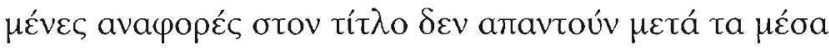
tov 12 ov atóva.

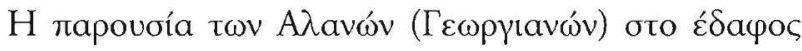

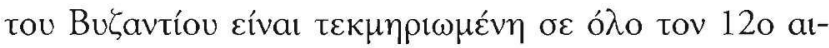

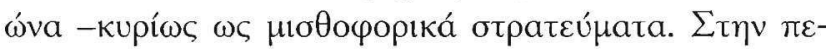

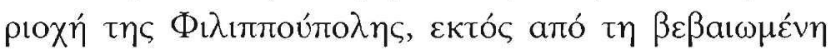

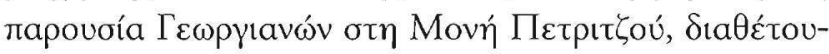

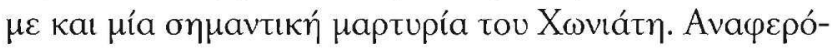

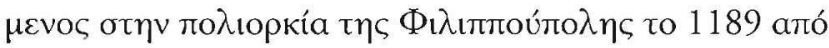

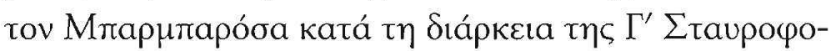

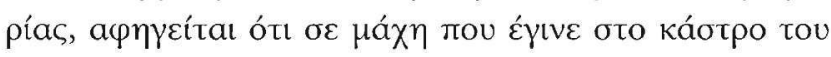

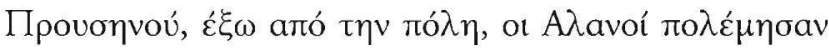

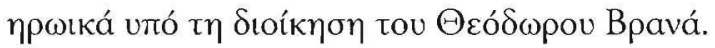

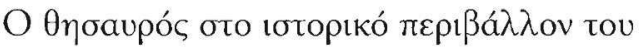

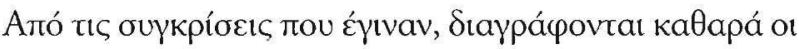

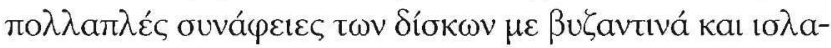

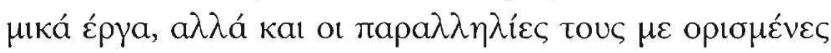

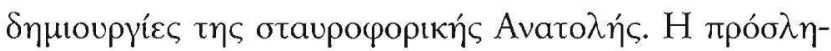

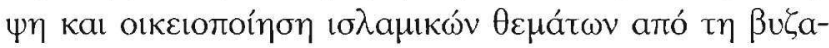

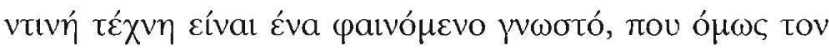

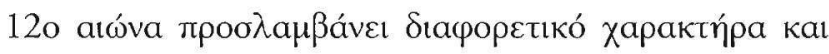

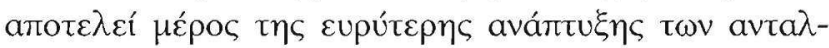

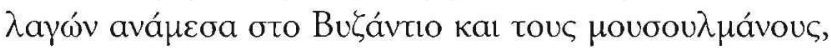

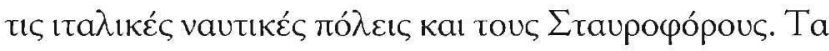

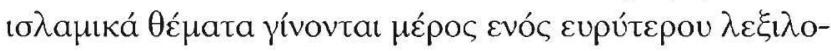

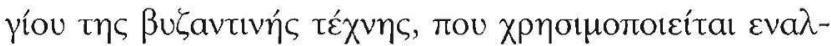

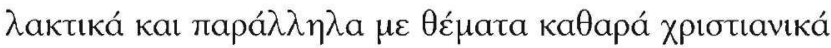

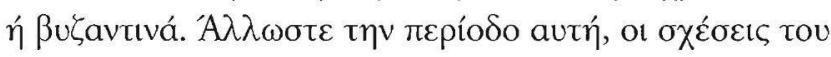

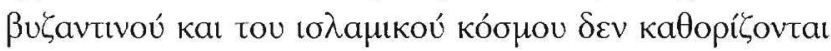

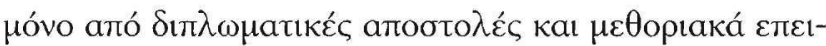

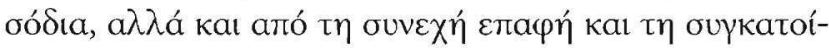

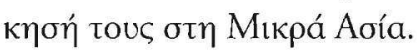

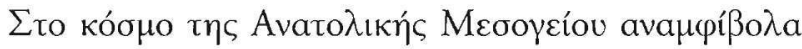

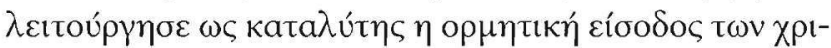

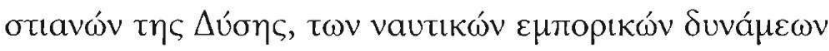

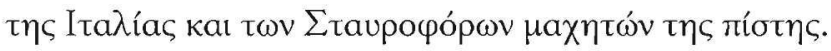

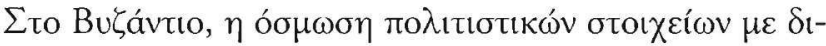

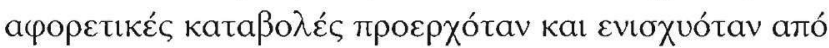

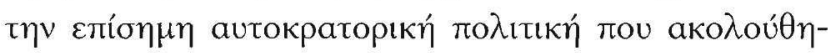

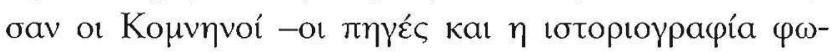




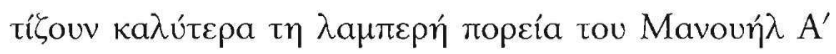

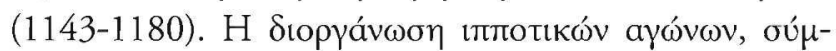

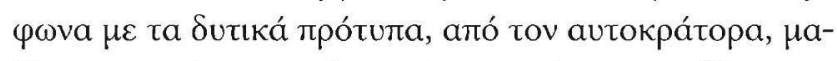

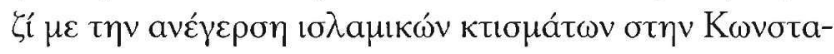

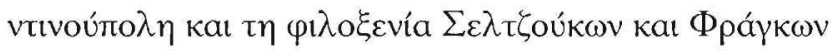

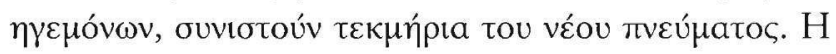

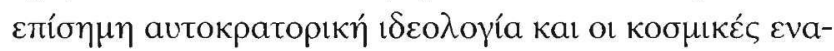

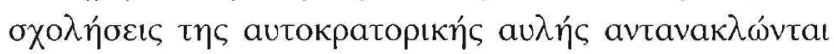

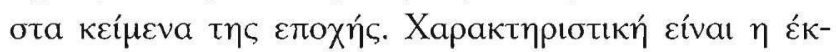

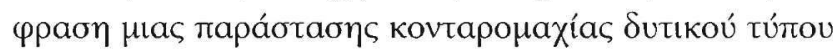

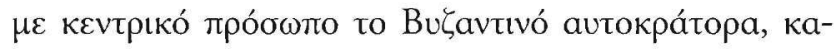

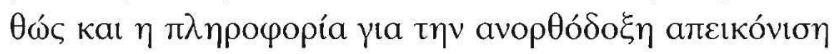

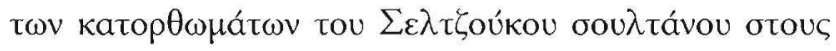

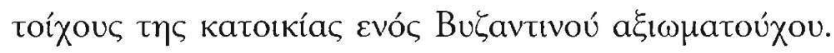

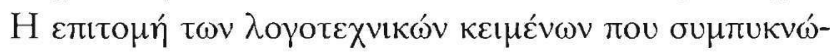

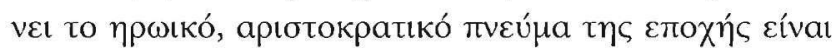

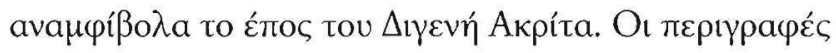

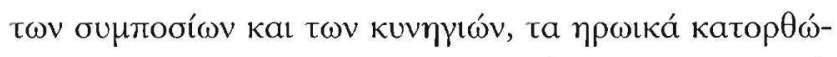

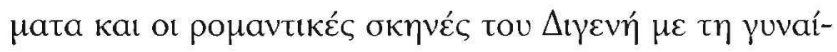

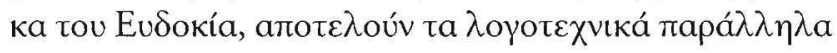

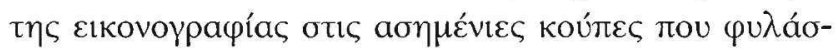
oovtaı oฑ́

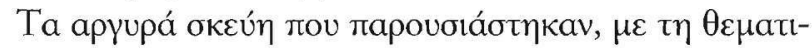

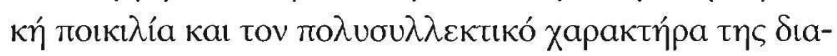

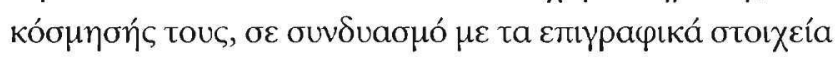

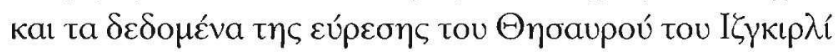

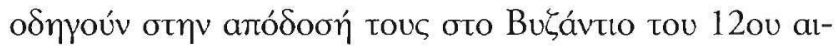

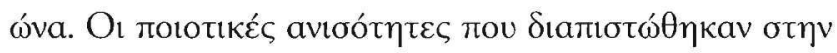

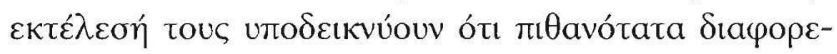

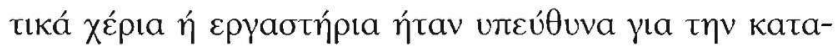

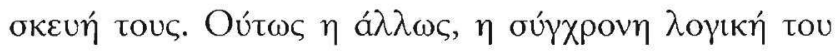

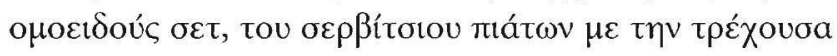

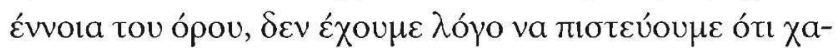

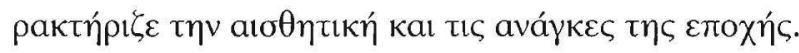

